\title{
The emission of volatile halocarbons by seaweeds and their response towards environmental changes
}

Fiona S.-L. Keng ${ }^{1,2}$, Siew-Moi Phang ${ }^{1,3^{*}}$, Noorsaadah Abd Rahman ${ }^{4}$,Emma C. Leedham Elvidge ${ }^{5,6}$, Gill Malin ${ }^{5}$, William T. Sturges ${ }^{5}$

${ }^{1}$ Institute of Ocean and Earth Sciences (IOES), Universiti Malaya, 50603, Kuala Lumpur, Malaysia. ${ }^{2}$ Institute of Advanced Studies (IAS), Universiti Malaya, 50603, Kuala Lumpur, Malaysia. ${ }^{3}$ Faculty of Applied Sciences, UCSI University, Cheras, 56000, Kuala Lumpur, Malaysia. ${ }^{4}$ Department of Chemistry, Universiti Malaya, 50603, Kuala Lumpur, Malaysia.

${ }^{5}$ Centre for Ocean and Atmospheric Sciences, School of Environmental Sciences, University of East Anglia, Norwich Research Park, Norwich NR4 7TJ, United Kingdom.

${ }^{6}$ Faculty of Science, University of East Anglia, Norwich Research Park, Norwich NR4 7TJ, United Kingdom.

"Corresponding Author:

Email: phang@um.edu.my

Contact Number: +60 379674610

Full Postal Address: Institute of Ocean and Earth Sciences (IOES), C308 IPS Building, University of Malaya, 50603 Kuala Lumpur, Malaysia.

\footnotetext{
Abstract

Volatile halocarbons can deplete the protective stratospheric ozone layer contributing to global climate change and may even affect local climate through aerosol production. These compounds are produced through anthropogenic and biogenic processes. Biogenic halocarbons may be produced as defence compounds, anti-oxidants, or by-products of metabolic processes. These compounds include very short-lived halocarbons (VSLH) e.g. bromoform $\left(\mathrm{CHBr}_{3}\right)$, dibromomethane $\left(\mathrm{CH}_{2} \mathrm{Br}_{2}\right)$, methyl iodide $\left(\mathrm{CH}_{3} \mathrm{I}\right)$, diiodomethane $\left(\mathrm{CH}_{2} \mathrm{I}_{2}\right)$. Efforts to quantify the biogenic sources of these compounds, especially those of marine origin e.g. seaweeds, phytoplankton and seagrass meadows, are often complicated by inherent biological variability as well as spatial and temporal changes in emissions. The contribution of the coastal region and the oceans to the stratospheric load of halocarbons has been widely debated. This highlights the need to understand the factors affecting the release of these compounds from marine sources for which data for modelling purposes are generally lacking. Seaweeds are important sources of biogenic halocarbons subjected to changing environmental conditions. Huge uncertainties in the prediction of current and future global halocarbon pool exist due to the lack of spatial and temporal data input from coastal and oceanic sources. Therefore,
} 
investigating the effect of changing environmental conditions on the emission of VSLH by the seaweeds could help towards better estimations of halocarbon emissions. This is especially important in light of global changes in both climate and the environment, the expansion of seaweed cultivation industry, and the interactions between halocarbon emission and their environment. In this paper we review current knowledge of seaweed halocarbon emissions, how environmental factors affect these emissions, and identify gaps in understanding. Our aim is to direct much needed research to improve understanding of the contribution of marine biogenic sources of halocarbons and their impact on the environment.

Keywords: Halocarbons; Bromoform; Air-Sea Gas Exchange; Climate Change; Environmental Change; Seaweed

\section{Acknowledgements}

This research was funded by the Phase II Higher Institution Centre of Excellence (HICoE) Fund, the Ministry of Education Malaysia (IOES-2014F), University of Malaya Top 100 Research University Grant (TU001D-2018) and the University of Malaya Postgraduate Research Funds, PPP (PG3002016A). 


\section{Introduction}

Research on biogenic very short-lived brominated compounds (e.g. $\mathrm{CHBr}_{3}, \mathrm{CH}_{2} \mathrm{Br}_{2}$ ) resurfaced (Ziska et al. 2013; Liang et al. 2014; Hossaini et al. 2016) in recent years due to knowledge of the increasingly significant contribution of very short-lived halocarbons (VSLH) to the tropospheric and stratospheric bromine load, which can potentially alter ozone abundance and radiative impact (Stemmler et al. 2015; WMO, 2018). Global ocean fluxes of $\mathrm{CHBr}_{3}$ and $\mathrm{CH}_{2} \mathrm{Br}_{2}$ range between 120 820 and $57-100 \mathrm{Gg} \mathrm{Br} \mathrm{yr}^{-1}$, while $\mathrm{CH}_{3} \mathrm{I}$ ranges between 157-550 $\mathrm{Gg} \mathrm{I} \mathrm{yr}^{-1}$ (WMO, 2018). The phytoplankton and cyanobacteria emit majority of the $\mathrm{CH}_{3} \mathrm{I}$ from the ocean (Saiz-Lopez et at. 2011; WMO, 2018). Short atmospheric lifetime of some of these compounds means that they can only reach the lower stratosphere through rapid convective uplifting, particularly from the tropics (Dessens et al. 2009). Reactive bromine constituted around 5 (3-7) ppt, or 25\%, of the total stratospheric bromine recorded in 2016 (WMO, 2018). This originates from short-lived bromocarbons i.e. $\mathrm{CHBr}_{3}$ and $\mathrm{CH}_{2} \mathrm{Br}_{2}$ (Liang et al. 2014). Bromine and iodine are more efficient than chlorine in depleting the ozone layer (Chipperfield and Pyle, 1998; Daniel et al. 1999), therefore it is important to understand their sources and quantify their emissions.

VSLH have been linked to climate change through their potential to deplete the protective stratospheric ozone layer, influence atmospheric chemistry, and contribute to local weather change and radiative forcing via cloud nuclei formation (Saiz-Lopez and von Glasow, 2012; Carpenter et al. 2014; Hossaini et al. 2015, WMO 2018). Variabilities and uncertainties in the current global estimates of oceanic halogen load, derived from top-down and bottom-up modelling, could arise from poor temporal and spatial data coverage (WMO 2018), and are commonly attributed to a lack of data for oceanic inputs and under-representation of coastal and extreme emissions (Ziska et al. 2013; Fuhlbrügge et al. 2016; Ziska et al. 2017). Spatial and temporal variation in production of compounds such as bromoform often leads to large uncertainties in production estimates while uncertainties in flux calculations arise from factors such as insufficient data input, varying levels of data precision and accuracy, the applied air-sea exchange parameterization, the use of average values that could yield pronounced uncertainties especially in regions where seasonality largely affects the air-sea exchange coefficient, and errors associated with extrapolation of data (Quack and Wallace, 2013).

Seaweeds are known to be emitters of the short-lived brominated compounds including $\mathrm{CHBr}_{3}$ and $\mathrm{CH}_{2} \mathrm{Br}_{2}$ and could contribute to significantly higher concentrations (up to three-fold) of $\mathrm{CHBr}_{3}, \mathrm{CHBr}_{2} \mathrm{Cl}, \mathrm{CH}_{2} \mathrm{Br}_{2}, \mathrm{CHIBr}_{2}, \mathrm{CH}_{2} \mathrm{IBr}$ and $\mathrm{CH}_{2} \mathrm{I}_{2}$ in coastal areas compared to areas further offshore (Yamamoto et al. 2001; Gibble, 2003; Keng et al. 2013; Leedham et al. 2013; Leedham Elvidge et al. 2015). The significant role of seaweeds in the production of bromoform, which is often the most abundant biogenic brominated halocarbon released by seaweeds, was first reported by 
Carpenter and Liss (2000): that seaweeds account to $70 \%$ of global bromoform production. Meanwhile, extrapolation of data from small-scale studies on tropical seaweeds in South-East Asia

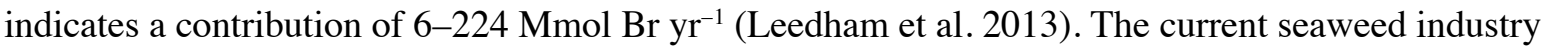
is expanding globally, and production doubled to 30.4 million tonnes from 2005 to 2015 (FAO, 2018). About 29.4 million tonnes is cultivated and this is dominated by the red seaweeds. The top cultivated seaweeds in the world in terms of biomass include the red carrageenophytes Eucheuma denticulatum and Kappaphycus alvarezii in tropical and sub-tropical waters, with a combined yield of 12 million tonnes in 2015 (FAO 2018). Thus, it is important to be able to estimate and predict the increased contribution of halocarbons from the seaweed industry, and especially in the Asian region (Phang et al. 2015).

Most seaweeds are benthic algae attached to hard substrates where sufficient light penetrates. Intertidal seaweeds are constantly exposed to rapidly changing environment due to the tidal cycle, which might create a stressful environment, though they have adapted to survive this. The combined effect, be it temporary or long-termed, of these interactions results in variations in physiology, growth, morphology and survival of the species (Harley et al. 2012). In the attempt to provide a comprehensive prediction of the global halocarbon budget, considerable efforts have been made to establish and to narrow down the environmental factors responsible for the enhanced emission of halocarbons by the seaweeds (Nightingale et al. 1995; Mtolera et al. 1996; Manley and Barbero, 2001; Abrahamsson et al. 2003; Carpenter et al. 2000; Bravo-Linares et al. 2010; Laturnus et al. 2010; Keng et al. 2013; Leedham Elvidge et al. 2015, Mithoo-Singh et al. 2017). Some of these studies were carried out in a controlled environment while others were conducted in situ. While a controlled study might provide more straightforward findings by excluding the many possible disturbances found in an in-situ study, in situ studies do embrace the complexity of the natural environment, providing a more realistic study scenario.

Photosynthesis and respiratory electron transport produces reactive oxygen species (ROS) such as the superoxide anion radical $\left(\mathrm{O}_{2}^{-}\right)$and hydrogen peroxide $\left(\mathrm{H}_{2} \mathrm{O}_{2}\right)$ (Rutherford et al. 2012; Wever and van der Horst, 2013). Light-dependent processes in seaweeds like pseudocyclic photophosphorylation or the Mehler reaction produce superoxide radicals $\left(\mathrm{O}_{2}^{-}\right)$, and subsequently $\mathrm{H}_{2} \mathrm{O}_{2}$, as a result of electron transport from the ferrodoxin of PSI to the oxygen molecule during the photosynthesis process (Collén et al. 1995; Manley and Barbero, 2001; Dummermuth et al. 2003). Under normal conditions, cellular ROS scavenging mechanisms involving enzymes such as superoxide dismutase are able to catalyze superoxide into $\mathrm{O}_{2}$ or $\mathrm{H}_{2} \mathrm{O}_{2}$, which could later form $\mathrm{OH}$ (Birben et al. 2012; Yakovleva et al. 2017; Younus, 2018). Oxidative stress arises when capacity of such mechanism is exceeded, resulting in the buildup of ROS in the seaweeds. Common factors 
triggering oxidative stress in seaweeds include grazing, microbial attack, exposure to varying environmental parameters like high light, desiccation, variations in temperature, salinity changes, carbon dioxide and nutrient limitation (Dietz 2016). The involvement of ROS produced during oxidative stress or through the efflux of iodide (Küpper et al. 2013) during an oxidative burst, results in the formation of halocarbons.

The production of halocarbons in seaweeds occur through bromoperoxidase activity in the seaweeds, which can catalyse production of polyhalogenated brominated and iodinated compounds. Involvement of S-adenosyl- methionine-dependent methyl transferase-type mechanism has also been reported in relation to the production of methyl halides (Almeida et al. 2001; Manley, 2002; Toda and Itoh, 2011; Yokouchi et al. 2014). The activities of methyl transferases yield monohalogenated compounds including $\mathrm{CH}_{3} \mathrm{Br}, \mathrm{CH}_{3} \mathrm{I}$, di- and polyhalogenated compounds such as $\mathrm{CHBr}_{2} \mathrm{I}$ (Milkova et al. 1997; Neilson, 2003; Amachi et al. 2006; Küpper et al. 2018). Punitha et al. (2017) gives a detailed explanation of the reactions. Trihalogenated compounds e.g. $\mathrm{CHBr}_{3}$ have been widely postulated to be the result of the oxidisation of halides by haloperoxidases (e.g. bromoperoxidase) using $\mathrm{H}_{2} \mathrm{O}_{2}$ to yield hypohalide, which then either reacts with the ketones in the seaweeds or dissolved organic matters (DOM) in the environment to produce haloform (Wever et al. 1991; Opsahl and Benner, 1997; Lin and Manley, 2012; Wever and ven der Horst, 2013; Liu et al. 2015). The formation of bromoform via the haloform pathway has been supported through an in vivo study on Asparagopsis (Küpper et al. 2014), and the availability and composition of dissolved organic matter has been reported to affect halocarbon emissions by seaweeds (Lin and Manley, 2012; Liu et al. 2015). Lin and Manley (2012) found higher halocarbon production from near-shore than offshore waters and during spring phytoplankton blooms. They attributed this to the involvement of DOM in the production of halocarbons, and the quantitative change between $\mathrm{CH}_{2} \mathrm{Br}_{2}$ and $\mathrm{CHBr}_{3}$ emissions to changes in DOM composition. Specific cell metabolites including mannose, glycolic acid, alginic acid, citric acid, humic acid, and urea all increase the production of brominated halocarbons (see Liu et al. 2015 for a complete list of the effect of different DOM compounds on the production of brominated volatile compounds). Meanwhile, unlike most halocarbons where their production resulted from stress and involved $\mathrm{H}_{2} \mathrm{O}_{2}$, the production of methyl halide involves only $S$-adenosyl-L-methionine and the presence of halides concentrated from surrounding seawater (Küpper et al. 2018).

Quack and Wallace (2013) discussed the role of $\mathrm{CHBr}_{3}$ in atmospheric chemistry, its distribution (based on a detailed compilation of mixing ratios and seawater $\mathrm{CHBr}_{3}$ measurements) and reflected on the possible reasons behind the high variability in $\mathrm{CHBr}_{3}$ emission estimations. The production of halocarbons, their role, impact on the environment and chemical destruction of halocarbon such as chloride substitution, hydrolysis and photolysis of bromoform have also been 
reviewed previously (Paul and Pohnert, 2011; Carpenter et al. 2012; Wever and van der Horst, 2013). Nonetheless, in the light of impending climate and environmental change, and the uncertainty of how halocarbon emissions by seaweeds will respond to these changes, it is timely to review how environmental factors affect the release of halocarbons by seaweeds.

\section{Aims and approaches}

This review will provide a comprehensive account of the effects of climate change on halocarbon emissions by seaweeds together with an updated list of references. Published emission rates of halocarbons from seaweeds, were used to identify the dominant halocarbons $\left(\mathrm{CHBr}_{3}, \mathrm{CH}_{2} \mathrm{Br}_{2}, \mathrm{CH}_{2} \mathrm{BrI}\right.$ and $\mathrm{CH}_{2} \mathrm{I}_{2}$ ) emitted by a range of seaweeds (Table 1). The effects of environmental changes on the halocarbon emission by seaweeds were tabulated (Table2). This was based on setting a specific level of an environmental parameter as a pre-set condition, and documenting the change in emission rate of halocarbon compounds when the seaweed was exposed to conditions differing from the pre-set condition. The geographic location of collection sites of the seaweeds used for these studies are presented in Fig. 1 to show where studies have focused on and which areas are under-represented in this analysis. Emission rates of the halocarbons were extracted from journal publications, while discussion incorporated information from WMO reports, chapters in books, as well as journal publications.

\section{Results}

Of the halocarbon compounds, seaweeds release significantly more $\mathrm{CHBr}_{3}$ than the others (Wever and van der Horst, 2013). This holds true for seaweeds from temperate, polar and tropical regions. Supporting evidence include a temperate rock pool study where emission of $\mathrm{CHBr}_{3}$ was highest among a suite of 13 iodinated and brominated halocarbons emitted by a population dominated by Laminariales and Fucales (Carpenter et al. 2000). A similar trend was observed for polar seaweeds. A comprehensive study by Laturnus (2001) showed that 29 out of a total of 30 polar seaweeds emitted $\mathrm{CHBr}_{3}$ as the major compound, with emission rates ranging from $0.7-645 \mathrm{pmol} \mathrm{g} \mathrm{FW}^{-1} \mathrm{hr}^{-1}$, with higher emission rates from brown polar seaweeds (Laturnus, 1995; Laturnus, 2001). Tropical seaweeds have also shown high $\mathrm{CHBr}_{3}$ emission rates (Keng et al. 2013; Leedham et al. 2013; Mithoo-Singh et al. 2017). $\mathrm{CH}_{2} \mathrm{Br}_{2}, \mathrm{CH}_{2} \mathrm{BrI}$ and $\mathrm{CH}_{2} \mathrm{I}_{2}$ as the dominant halocarbon released were also reported from tropical seaweeds (Table 1; Leedham et al. 2013). Baker et al. (2001) investigated the emission of $\mathrm{CH}_{3} \mathrm{Br}, \mathrm{CH}_{3} \mathrm{Cl}, \mathrm{CH}_{3} \mathrm{ClI}$ and $\mathrm{C}_{2} \mathrm{H}_{5} \mathrm{I}$ by temperate seaweeds and found that the emission rates were relatively low at between magnitude of $10^{-4}$ to $10^{1} \mathrm{pmol} \mathrm{g} \mathrm{DW}^{-1} \mathrm{hr}^{-1}$.

From Table 1 it can be seen that red $\left(0.71-4960 \mathrm{pmol} \mathrm{g} \mathrm{FW}^{-1} \mathrm{hr}^{-1}\right)$ and brown seaweeds $(0.1$ $-1100 \mathrm{pmol} \mathrm{g} \mathrm{FW}^{-1} \mathrm{hr}^{-1}$ ) are strong emitters of $\mathrm{CHBr}_{3}$, with lower emission rates reported for green 
seaweeds $\left(0.4-344 \mathrm{pmol} \mathrm{g} \mathrm{FW}^{-1} \mathrm{hr}^{-1}\right)$. Polar seaweeds generally showed lower emission rates than tropical and temperate seaweeds, except for a few brown species. The highest emission seen for a polar brown alga was for Desmarestia anceps (645 $\mathrm{pmol} \mathrm{g} \mathrm{FW}^{-1} \mathrm{hr}^{-1}$, Laturnus, 2001). Amongst the recorded species, the $\mathrm{CHBr}_{3}$ emission rate was exceptionally high for the temperate red seaweed, Asparagopsis armata at $4960 \mathrm{pmol} \mathrm{g} \mathrm{FW}^{-1} \mathrm{hr}^{-1}$ (Carpenter et al. 2000). These data however, were compiled from multiple experiments with different settings and objectives of study. Therefore, comparisons between emission rates should be executed with caution.

\section{Herbivory}

Most seaweeds survive by attaching themselves to a substrate with their holdfast in order to prevent the tidal waves from sweeping them away. They are constantly exposed to grazing pressures from fish, sea urchins, crustaceans and molluscs and unable to evade predators and parasites, but seaweeds are thought to have developed a range of defense mechanisms to prevent grazer and pathogen attacks. They can reduce or even avoid predation through metabolic reconfiguration involving coordination in the expression of numerous defence-related genes (reviewed by Kessler and Baldwin, 2002), some of which lead to emissions of halogenated compounds that are effective against herbivores and microorganisms (Ohsawa et al. 2001; Paul et al. 2006; Paul and Pohnert, 2010).

Some studies investigating the effect of tissue wounding on seaweeds reported increases in the emission of halocarbon compounds (Table 2). When wounded by grazing-snails over 24 hours, the release rate of halocarbon e.g. $\mathrm{CHCl}_{3}$ by Ascophyllum nodosum was ten times higher (10.5 - 10.8 pmol $\left.\mathrm{g} \mathrm{DW}^{-1} \mathrm{hr}^{-1}\right)$ than the control (1.26 $\mathrm{pmol} \mathrm{g} \mathrm{DW}^{-1} \mathrm{hr}^{-1}$; Nightingale et al. 1995). Although no statistical significance was indicated, the release of other compounds i.e. $\mathrm{CHBr}_{3}, \mathrm{CH}_{2} \mathrm{Br}_{2}, \mathrm{CHBrCl}_{2}$ were also enhanced through grazing (Nightingale et al. 1995, Table 2, Study 1). However, longer grazing period could increase the resistance level among the seaweeds especially the green and brown seaweeds (Toth and Pavia, 2007), which might affect the halocarbon release by the seaweeds. Investigation into longer wounding exposure by grazers would be interesting. Meanwhile, Sundström et al. (1996) triggered tissue wounding by cutting the sub-tropical species, Eucheuma denticulatum and this also increased the emission of $\mathrm{CHBr}_{3}$ (Table 2, Study 2).

\section{Microbial defense}

Seaweeds are able to detect pathogen invasion through cell-level recognition of signal molecules from the invading organism or their own cell wall. Such compounds, also known as elicitors, include oligosaccharides, peptidoglycans, and lipoteichoic acid (Amsler 2008; de Oliveira et al. 2017). The brown seaweeds belonging to the families Laminariales, Desmarestiales, Ectocarpales, and Fucales, 
are able to rapidly detect the signals for defense elicited by simple addition of alginate oligosaccharides (Küpper et al. 2002; Amsler 2008; Chance et al. 2009).

The response of seaweeds towards microbial attacks was studied in the temperate brown seaweed, Laminaria digitata, a very well-known iodine bioaccumulator among living organisms. The response of halocarbon emissions upon exposure to the elicitors has been investigated. While oligoguluronate is a breakdown product of the cell wall following a bacterial attack, $\mathrm{H}_{2} \mathrm{O}_{2}$ is produced during the oxidative burst following the induction of oligoguluronate. The oxidative burst is a typical rapid transcient response after plant defence elicitation, producing large amounts of reactive oxygen species, and commonly involves cell-cell recognition (Küpper et al. 2001). Palmer et al. (2005) reported increased halocarbons and $\mathrm{I}_{2}$ emissions by L. digitata. When subjected to oligoguluronates, the emission of iodinated compounds i.e. $\mathrm{CH}_{2} \mathrm{I}_{2}$ and $\mathrm{CH}_{2} \mathrm{ClI}$ seemed stronger than when subjected to $\mathrm{H}_{2} \mathrm{O}_{2}$. However, when the seaweed was exposed to $\mathrm{H}_{2} \mathrm{O}_{2}$, the emissions of brominated compounds $\mathrm{CHBr}_{3}$ and $\mathrm{CHBr}_{2} \mathrm{Cl}$ seemed stronger than the emission of iodinated compounds. Similar trends were also reported by Collén et al. (1994) in the red seaweed Meristiella gelidium (Pédersen et al. 1996; See Palmer et al. 2005 for comparison between values). Increased amounts of halogenated compounds of up to eight-fold were also produced through the oxidative burst response to agar oligosaccharides in Gracilaria sp. (Weinberger et al. 2007; Table 2 Study 3 and 4). It is evident that microbial attack can elevate the emission of halocarbons via the scavenging of reactive oxidants: Chance et al. (2009) reported up to 20-fold elevated emission of iodide by L. digitata upon treatment with oligoguluronate elicitors.

L. digitata stores iodine in the form of inorganic iodide in the apoplast and young sporophytes are capable of accumulating up to 30,000 times more iodine than the surrounding seawater (Küpper et al. 1998; Verhaeghe et al. 2008). The iodide acts an inorganic antioxidant, capable of quenching aqueous oxidants through efflux into the surrounding water. Iodocarbons e.g. $\mathrm{CH}_{2} \mathrm{I}_{2}$ and $\mathrm{CHI}_{3}$ are produced after an initial burst of reactive oxidant scavenging (Küpper et al. 2008). Therefore, instead of an anti-oxidative function, the formation of iodocarbons by L. digitata was suggested as a defense function against microbial growth due to the harmful nature of the released iodide following nucleophilic substitutions. The ability to volatize iodine into $\mathrm{CH}_{3} \mathrm{I}$ was also reported for filamentous fungi (Tadaaki et al. 2006).

\section{Oxidative stress due to the environment}

\subsection{Irradiance}

Harvesting light energy is fundamental to the survival of seaweeds. As seaweeds grow at various depths along the seabed in their natural habitat, the quality and quantity of irradiance, which is also 
related to the turbidity of the seawater, affects their photosynthetic responses and metabolic patterns. Irradiance is often varied in terms of duration as well as intensity. Variation arises due to seasonal changes especially in the Polar Regions where weeks of polar day or night are experienced during the polar summer and winter respectively. Variations also occur over the shorter diurnal time frame due to the angle of sun, where irradiance level starts increasing with the break of dawn, peaks at noon and decreases until sun set, or as a result of the continuous ebb and flood of tides. Transient changes in the quantity of light reaching the surface of the marine plants also arise from meteorological changes in cloud distribution, alteration in runoff and suspended sediment loads, the movement of seaweed fronds in the water column (self-shading and shading by neighbour seaweeds) and microbial blooms.

\subsubsection{Light vs. dark}

In order to observe the different responses in the emission of halocarbons by seaweeds under illumination and in the dark, halocarbon emissions by seaweeds have been quantified in several experiments (summarized in Table 2 Studies 6-16) and the observations reveal general agreement that halocarbons were emitted in a higher concentration under illuminated conditions than in the dark (Mtolera et al. 1996; Carpenter et al. 2000; Manley and Barbero, 2001; Keng et al. 2013).

An incubation-based study using glass vessels under natural light showed at least two-fold increase in halocarbon emissions by Laminaria digitata compared to the dark (ten times higher for $\mathrm{CHBr}_{3}$ ) (Carpenter at al, 2000). They found that $\mathrm{CHBr}_{3}$ increased ten-fold in the light compared to the dark. Nightingale et al. (1995) considered Ascophyllum nodosum and showed increased rates of halocarbon emissions in the light, with the exception of $\mathrm{CH}_{3} \mathrm{I}$, under an indoor artificial light/dark cycle setting and with an incubation period of 48 hours. The emission of $\mathrm{CHBr}_{3}$ by the temperate green seaweed, Ulva lactuca was also elevated by up to three times under illuminated conditions $\left(1.11 \pm 1.61 \mathrm{pmol} \mathrm{cm}^{-2} \mathrm{hr}^{-1}\right)$, compared to the dark $\left(0.25 \pm 0.40 \mathrm{pmol} \mathrm{cm}^{-2} \mathrm{hr}^{-1}\right)$ (Manley and Barbero, 2001). The emission rates were lower than those reported by L. digitata in the Carpenter et al. (2000) study mentioned above. However, the emission of $\mathrm{CHBr}_{3}$ decreased with prolonged incubation of $U$. lactuca in the dark for up to 14 days. Continued darkness for 14 days decreases respiration rate of $U$. lactuca, and a linear correlation between $\mathrm{CHBr}_{3}$ production and the logged values of respiration rate throughout the dark incubation period was established (Manley and Barbero, 2001; Table 2 Study 22).

Other reports by Bravo-Linares et al. (2010) and Laturnus et al. (2000) have shown higher halocarbon emission rates for several temperate and polar seaweeds with exposure to increased irradiance for between 12 hours and 3 months (Table 2 Studies 9, 12-15). The seaweeds were either incubated under natural condition near their habitat or given an artificial light/dark treatment with the aim of making as little disturbances to the natural light regime as possible. The seaweeds showed 
elevated halocarbon concentrations after $12 \mathrm{~h}$ of illumination as compared to a $12 \mathrm{~h}$ dark treatment (Bravo-Linares et al. 2010). When halocarbon concentrations were profiled at 3, 6, 9 and 12 hours after light treatment, the release of $\mathrm{CHBr}_{3}$ and $\mathrm{CH}_{2} \mathrm{I}_{2}$ by L. digitata and Ulva lactuca showed an increase in the concentrations from 3 to 12 hours. Concentrations of $\mathrm{CHBr}_{3}$ by seaweeds including Ascophyllum nodosum, Fucus vesiculosus, Fucus serratus, Ulva intestinalis, Palmaria palmata and Griffithsia flosculosa however, showed increase from 3 to 9 hours, and decreased at 12 hours posttreatment. The emission rates were not provided (Bravo-Linares et al. 2010). The different concentrations at different light exposure intervals provided insight into the possible responses of seaweeds to day length changes in the natural environment, and thoughts of how seaweeds from different habitats or tidal depths would respond to prolonged changes in irradiance in terms of the halocarbon emissions.

\subsubsection{Emissions at varying irradiance level}

Given that the presence of light triggers the emission of halocarbons by seaweeds, this suggests the process could be related to photosynthesis (see section entitled Photosynthesis), so investigating the effect of varying irradiance levels on halocarbon emission by the seaweeds could give interesting insight into the mechanisms responsible. Since higher irradiance levels could result in more hydrogen peroxide being released by the algal cells by triggering oxidative stress (Collén et al. 1995; Collén and Pedersén, 1999), one could postulate that this might then be accompanied by higher emission of halocarbons by the seaweeds.

Three short term (less than 24 hours) incubation studies showed that when seaweeds were exposed to varying irradiance levels under controlled laboratory conditions, their halocarbon emission rates increased with the intensity of the irradiance (Mtolera et al. 1996; Sundström et al. 1996; Keng et al. 2013). In a commercially important tropical seaweed collected from Tanzania, Eucheuma denticulatum, the production of $\mathrm{CHBr}_{3}$, which was linearly correlated to the brominating activity of the seaweed $(r=1.0 ; p<0.05)$, increased up to five fold $\left(6120 \pm 1764 \mathrm{pmol} \mathrm{g} \mathrm{FW}^{-1} \mathrm{hr}^{-1}\right)$ at light intensity of $600 \mu \mathrm{mol}$ photon $\mathrm{m}^{-2} \mathrm{~s}^{-1}$ compared to the dark $\left(1224 \pm 684 \mathrm{pmol} \mathrm{g} \mathrm{FW}^{-1} \mathrm{hr}^{-1}\right)$ and at 15 $\mu \mathrm{mol}$ photon $\mathrm{m}^{-2} \mathrm{~s}^{-1}\left(1224 \pm 360 \mathrm{pmol} \mathrm{g} \mathrm{FW}^{-1} \mathrm{hr}^{-1}\right)$ through the measurement of tetrabromophenol concentrations (Sundström et al. 1996; Table 2 Study 6). The seaweed was previously cultivated at 70 $\mu \mathrm{mol}$ photon $\mathrm{m}^{-2} \mathrm{~s}^{-1}$ with 12:12 $\mathrm{hr}$ light period. Using the same seaweed species, Mtolera et al. (1996) also reported higher release rates for seven halocarbons i.e. $\mathrm{CHBr}_{3}, \mathrm{CH}_{2} \mathrm{I}_{2}, \mathrm{CHBr}_{2} \mathrm{Cl}_{1} \mathrm{C}_{2} \mathrm{Cl}_{4}, \mathrm{CH}_{2} \mathrm{CII}$, sec- $\mathrm{C}_{4} \mathrm{H}_{9} \mathrm{I}$ and $\mathrm{CHCl}_{3}$ when light intensities increased from 400 to $1500 \mu \mathrm{mol}$ photon $\mathrm{m}^{-2} \mathrm{~s}^{-1}$ for an hour (Mtolera et al. 1996; Table 2 Study 6). The laboratory-cultivated seaweed was maintained at 350 $\pm 50 \mu$ mol photon $\mathrm{m}^{-2} \mathrm{~s}^{-1}$ upon collection. The emission rates of $\mathrm{CHBr}_{3}$ increased from 388 to 556 and 322 to $641 \mathrm{pmol} \mathrm{g} \mathrm{DW}^{-1} \mathrm{hr}^{-1}$ at $\mathrm{pH}$ of 8.2 and 8.8 respectively (Mtolera et al. 1996). Their 
observations were based on the exposure of the seaweed to either 400 and $1500 \mu \mathrm{mol}$ photon $\mathrm{m}^{-2} \mathrm{~s}^{-1}$ for one hour. Our own study on the tropical brown seaweeds Sargassum binderi, Turbinaria conoides and Padina australis from Port Dickson, Malaysia (Keng et al. 2013; Table 2 Studies 17-19) showed positive correlations (Pearson Correlation Coefficient, $r, 0.6-0.9, p<0.01$ ) between increasing irradiance levels $\left(0-126 \mu \mathrm{mol}\right.$ photon $\left.\mathrm{m}^{-2} \mathrm{~s}^{-1}\right)$ and the emissions of $\mathrm{CH}_{2} \mathrm{BrI}, \mathrm{CH}_{2} \mathrm{I}_{2}$ and the brominated compounds $\mathrm{CH}_{2} \mathrm{Br}_{2}, \mathrm{CHBr}_{3}$ and its derivatives, $\mathrm{CH}_{2} \mathrm{BrCl}, \mathrm{CHBrCl}_{2}$, and $\mathrm{CHBr}_{2} \mathrm{Cl}$. The emission of $\mathrm{CHBr}_{3}$ increased from $4.7 \pm 16$ to $714 \pm 127 \mathrm{pmol} \mathrm{g} \mathrm{DW}^{-1} \mathrm{hr}^{-1}, 279 \pm 32.2$ to $2400 \pm 452$ pmol $\mathrm{g} \mathrm{DW}^{-1} \mathrm{hr}^{-1}$ and $0.7 \pm 0.1$ to $27.8 \pm 3.8 \mathrm{pmol} \mathrm{g} \mathrm{DW}^{-1} \mathrm{hr}^{-1}$ by the three seaweeds respectively when light increased from 0 to $126 \mu \mathrm{mol}$ photon $\mathrm{m}^{-2} \mathrm{~s}^{-1}$. The seaweeds were kept in a hatchery at ambient light condition post-collection and prior to experiment use. The results were obtained after a fourhour exposure to five different irradiance levels under controlled laboratory conditions, indicating the possible influence of natural environmental changes on the emission of these compounds.

In addition to the findings from the laboratory-based controlled studies, similar trends have also been observed in studies investigating the effect of diurnal light changes on halocarbon emissions in rockpools with temperate seaweed species (Table 2 Studies 23-24). Increased emissions of halocarbons were observed with increased irradiance level from dawn to midday, with concentrations 2-fold higher near mid-day compared to pre-dawn despite temperature being almost constant (Carpenter et al. 2000). The concentration of $\mathrm{CHBr}_{3}$ and $\mathrm{CH}_{2} \mathrm{I}_{2}$ released by the rockpool algae were above 300 and $8 \mathrm{pmol} \mathrm{L}^{-1}$ respectively near mid-day and below 160 and $5 \mathrm{pmol} \mathrm{L}^{-1}$ before $7 \mathrm{am}$ (Carpenter et al. 2000). A similar pattern (Table 2 Study 24) was reported by Ekdahl et al. (1998) for a rockpool in the Canary Islands, Spain where an increase in the halocarbon concentration was reported for mid-day in air and seawater samples. In addition, there was another spike in the halocarbon concentration after sunset that the authors attributed to algal respiration (Ekdahl et al. 1998). The first rockpool study (Nightingale et al. 1995) showed rapid increase in concentrations of $\mathrm{CH}_{2} \mathrm{I}_{2}, \mathrm{CH}_{2} \mathrm{Br}_{2}$ and $\mathrm{CHBr}_{3}$ for six hours when the rockpool was isolated during the tidal cycle. Seaweeds found inside the rockpool include Fucus serratus, Ascophyllum nodosum, Dumontia contorta, Enteromorpha sp, Cladophora albida, Chaetomorpha sp. and Gigartina stellata (Nightingale et al. 1995). Data for irradiance, however, was not provided, and the increase in halocarbon concentration could be due to increase in temperature and $\mathrm{pH}$, as well as accumulation over time.

The collective evidence shows that higher irradiance levels elevate halocarbon emissions in seaweeds. Diurnal patterns drive changes in many environmental factors such as irradiance, temperature, seawater depth, as well as photosynthetic and other related metabolic activities, so these parameters are intimately related. Physical constraints such as tidal interval (Stewart et al. 2013) pose 
constraints and challenge for in situ studies in the intertidal zone but nonetheless this is an important consideration in halocarbon studies where the interactive effects of multiple environmental drivers are likely to be important. Single stressor studies remain beneficial in providing useful understanding on halocarbon emissions by seaweeds, but more in situ studies are needed to provide a better representation of natural seaweed halocarbon emission rates in nature.

\subsubsection{Regional considerations}

Most of the studies discussed so far concern halocarbon emissions from temperate and tropical seaweeds. Here we briefly consider halocarbon versus light data for seaweeds from the Antarctic. The growth season is relatively short for Earth's polar regions, especially compared to the Tropics, and there are periods in the seasonal cycle with close to continuous light or dark conditions.

Laturnus et al. (1998) reported higher release rates of halocarbons in general (except $\mathrm{CHBr}_{3}$, $\mathrm{CH}_{2} \mathrm{Br}_{2}$ and $\mathrm{CHBrCl}_{2}$ ) at low irradiance level or in darkness by Antarctic seaweeds, including the red alga Gymnogongrus antarcticus at irradiances of $0-80 \mu \mathrm{mol}$ photon $\mathrm{m}^{-2} \mathrm{~s}^{-1}$ (Table 2 Studies 9 and 20). Their findings were somewhat species-dependent and they did note differences in the physical appearance of the seaweeds collected: the eulittoral seaweed, Ulva compressa (formerly Enteromorpha compressa) was able to retain its green thallus colour at higher photon fluxes of 50 $80 \mu \mathrm{mol} \mathrm{m}^{-2} \mathrm{~s}^{-1}$, while lower sublittoral seaweeds e.g. Phycodrys quercifolia, Georgiella confluens, were completely bleached these light intensities (Laturnus et al. 1998). The bleaching in seaweeds can be attributed to environmental stress and reduced photosynthetic yield (Zou et al. 2017), therefore potentially affecting the halocarbon emissions (See Photosynthesis section). Overall the relationship between light intensity and halocarbon release was indistinct. In another study, a longer term twomonth exposure to irradiance at $15 \mu \mathrm{mol}$ photon $\mathrm{m}^{-2} \mathrm{~s}^{-1}$ or darkness was found to exert no obvious influence on the halocarbon emissions by G. antarcticus. However, at a higher irradiance of $30 \mu \mathrm{mol}$ photon $\mathrm{m}^{-2} \mathrm{~s}^{-1}$, both short (24 hours) and long term (two months) exposures triggered the enhancement of halocarbon emissions by the seaweed (Laturnus et al. 2000; Table 2 Study 9).

The reasons behind the differences in halocarbon emissions by seaweeds from different regions and shore zones is hard to ascertain and further research on the potential for biogeographic variation is warranted. This is particularly true for the polar regions that are undergoing highly significant environmental and climatic change and 'baseline' data is very limited. However, there are many other geographic areas where data are also sparse, limited by season, by the species examined or the incubation methods applied.

\subsubsection{Photosynthesis}


In the irradiance-related experiments, several authors have attributed the increase of seaweed halocarbon emissions of halocarbons with exposure to increased irradiance level to the underlying influence of photosynthetic activity. Indeed, irradiance is indispensable for the generation of chemical potentials for the fixation and reduction of inorganic carbon during photosynthesis.

While investigating the possible constraints on the production of $\mathrm{CHBr}_{3}$ in Ulva lactuca, Manley and Barbero (2001) found decreased production of $\mathrm{CHBr}_{3}$ to $47 \%$ of the amount of $\mathrm{CHBr}_{3}$ produced $\left(1.49 \mathrm{pmol} \mathrm{cm}^{-2} \mathrm{hr}^{-1}\right)$ in the light (control) condition, when the photosynthetic inhibitor, DCMU [3-(3,4-dichlorophenyl)-1,1-dimethylurea] was dissolved in the incubation seawater. This observation agrees with the hypothesis that irradiance influences the emission of halocarbon by seaweeds via a photosynthesis-related mechanism (Goodwin et al. 1997; Ekdahl et al. 1998). Ekdahl et al. (1998) reported the highest halocarbon emission rates for temperate seaweeds dominated by Cystoseria abies-marina (See Table 2 Study 23 for the name of seaweeds investigated) at mid-day when seaweed photosynthesis is generally maximal (Ekdahl et al. 1998). In studies on the giant kelp, Macrocystis pyrifera, Goodwin et al. (1997) confirmed the absence of $\mathrm{CHBr}_{3}$ and $\mathrm{CH}_{2} \mathrm{Br}_{2}$ when the seaweeds were incubated under illuminated conditions with DCMU.

Many recent algal studies have utilized a convenient and non-invasive way of measuring the efficiency of photosystem (PS) II through the use of pulse amplitude modulated (PAM) fluorometry. Here the parameter $F_{v} / F_{m}$, the ratio of variable to maximum chlorophyll fluorescence, is taken as a measure of non-cyclic photosynthetic electron flow capacity which is sensitive to changes in abiotic factors including light and nutrient deficiency. In the field of halocarbon measurements, the measurement of $F_{v} / F_{m}$ has been used for seaweeds by Keng et al. (2013), who found positive correlations (Table 2 Studies 27-28), (Pearson Correlation Coefficient, $r, 0.6-0.9, \mathrm{p}<0.01$ ) between $\mathrm{F}_{\mathrm{v}} / \mathrm{F}_{\mathrm{m}}$ and emissions of volatile brominated and iodinated compounds of the tropical brown seaweeds, Sargassum binderi and Padina australis.

\subsection{Ultraviolet radiation $(U V)$}

Excessive UVA $(320-400 \mathrm{~nm})$ and UVB $(290-320 \mathrm{~nm})$ can affect primary productivity in seaweeds through damaging critical cell components. Exposure to these UV wavebands has been related to decreases in photosynthetic activity, including the loss of Photosystem II, the electron transport system, a decrease in chlorophyll content and an increase in radical formation in algae. Less damage is caused by UVB than UVA (White and Jahnke, 2002; Xue et al. 2005; Figueroa et al. 2009). The inhibition of photosynthesis in seaweeds exposed to UVB is species-dependant, and may be influenced by their habitat e.g. seaweeds from deep sublittoral zones are more sensitive towards UVB exposure than those from shallow-water (Bischof et al. 2009). 
Though multiple studies have investigated the effect of increased radiation on seaweeds, only one study to date has looked at the response of seaweeds to UV in terms of halocarbon emissions. UV causes DNA damage through dimerisation, though the repair mechanism could be slowed down for polar plants where temperature is low (Björn et al. 1999). In investigating the effect of UV on polar seaweeds, Laturnus et al. (2010) subjected unialgal culture of the brown seaweed Saccharina latissima to UVA $\left(7.7 \mathrm{~W} \mathrm{~m}^{-2}, 320-400 \mathrm{~nm}\right)$ and UVB $\left(0.70 \mathrm{~W} \mathrm{~m}^{-2}, 280-320 \mathrm{~nm}\right)$. Noon surface levels of UVA and UVB on a clear day was reportedly around $19 \mathrm{~W} \mathrm{~m}^{-2}$ and $1.1 \mathrm{~W} \mathrm{~m}^{-2}$ respectively (Bischof et al. 1998; Laturnus et al. 2010). The results showed that, with the exception of $\mathrm{CH}_{3} \mathrm{I}$, most of the halocarbons analysed showed no significant changes when exposed to UV for 4 hours. However, with a longer irradiation period of 28 days, the presence of UV significantly affected the sum of reactive organic halogens (chlorine and iodine) released by the seaweed (Table 2 Study 31 ). Longer exposure to UV of 28 days increased emissions of reactive iodine, while decreasing emissions of reactive chlorine (Laturnus et al. 2010).

Although it is premature to conclude on the effect of increased UV on the halocarbon emission by seaweeds, this observation provides a useful observation on the possible effect of UV on polar seaweeds, which could also affect seaweeds from other region. This is albeit the fact that ozone loss (and therefore UV enhancement) over the tropics has been small compared to mid and high latitudes, and emissions from polar species are unlikely to contribute to stratospheric ozone loss. A better understanding of the effect of UV on the halocarbon emissions of seaweeds could contribute to modelling of potential seaweed emissions from different depths, latitudes, water turbidity conditions, intertidal position, etc. It is especially important for assessing the contribution of cultivated seaweeds towards the halocarbon budget, as seaweeds are often farmed just below the water surface, in shallow, clear, tropical waters, which are far more sensitive to UV flux.

\subsection{Temperature}

Temperature affects the enzyme activities and growth of seaweeds, and the tolerance level varies between species and even intra-species, whereby factors such as geographical distribution could affect the response levels observed when seaweeds are collected from different regions (Raikar et al. 2001). Changes in temperature could induce biome transformation, species loss, extinctions, and phenology changes, as well as altered physiology in seaweeds, including photosynthetic activities (Harley et al. 2012; de Bettignies et al. 2018). An investigation on the red seaweed Gracilariopsis lemaneiformis showed an increased rate of photosynthesis from $\sim 30 \mu \mathrm{mol} \mathrm{O}_{2} \mathrm{~g}^{-1} \mathrm{FW} \mathrm{hr}{ }^{-1}$ to $70 \mu \mathrm{mol} \mathrm{O}_{2} \mathrm{~g}^{-1} \mathrm{FW} \mathrm{hr}$ ${ }^{1}$ when temperature was increased from $12^{\circ} \mathrm{C}$ to $26^{\circ} \mathrm{C}$ (Zou and Gao, 2014). A model had been developed that showed +2 and $+4{ }^{\circ} \mathrm{C}$ in seawater temperature from the normal temperature of $14^{\circ} \mathrm{C}$ 
would lead to significant increase in photosynthesis activities of seaweeds from the Washington coastline (Colvard et al. 2014).

Although responses of seaweeds in terms of their halocarbon emissions after exposure to varied temperatures settings have been reported in the literature, the numbers are still limited, with only 5 temperate and 1 polar seaweed investigated so far. In their study on five brackish-water algal species, Abrahamsson et al. (2003) did not see a general response pattern, suggesting that halocarbon emission rates by seaweeds are strongly species-dependent. When the emission of $\mathrm{CH}_{2} \mathrm{I}_{2}$ by Cladophora glomerata was determined at $23^{\circ} \mathrm{C}$ in the laboratory, the emission of those grown at the same temperature in the field ceased $\left(0 \pm 0 \mathrm{pmol} \mathrm{g}\right.$ ash-free dry weight $\left.\mathrm{h}^{-1}\right)$ compared to those grown at $12^{\circ} \mathrm{C}\left(8.6 \pm 1.7 \mathrm{pmol} \mathrm{g}\right.$ ash-free dry weight ${ }^{-1} \mathrm{hr}^{-1}$; Abrahamsson et al. 2003; Table 2 Studies 33 and 34). Insignificant changes in the emissions of $\mathrm{CHBr}_{3}, \mathrm{CH}_{2} \mathrm{I}_{2}$ and $\mathrm{CHCl}_{3}$ from C. glomerata and Ulva ahlneriana was observed under a $10 \mathrm{hr}$ cross-incubation experiment where seaweeds growing at $12^{\circ} \mathrm{C}$ were incubated at $23^{\circ} \mathrm{C}$ and vice versa (Abrahamsson et al. 2003; Table 2 Studies 33 and 34). Similar studies on the Antarctic red seaweed Gymnogongrus antarcticus, showed around two-fold increased production of $\mathrm{CHBr}_{3}$ in a short-term $24 \mathrm{hr}$ incubation experiment where the temperature was increased from $0^{\circ} \mathrm{C}$ (standard culture condition with light intensity of $15 \mu \mathrm{mol} \mathrm{m}^{-2} \mathrm{~s}^{-1}$ ) to $10^{\circ} \mathrm{C}$ (with light intensity of $30 \mu \mathrm{mol} \mathrm{m} \mathrm{m}^{-2} \mathrm{~s}^{-1}$ ). The emission of $\mathrm{CHBr}_{3}$ was lower compared to standard culture conditions when the incubation period was extended to two months under the same temperature regime (Laturnus et al. 2000; Table 2 Study 32). Part of the two-fold increase in the short-term incubation experiment could be attributed to the increase in irradiance (from 15 to $30 \mu \mathrm{mol} \mathrm{m}^{-2} \mathrm{~s}^{-1}$ ).

The direct effect of temperature on halocarbon emissions could be difficult to decipher as the change in temperature could affect anything from a single reaction step to an entire pathway of reactions involved in the formation of halocarbons. Even this ignores the different temperature tolerance ranges exhibited by seaweeds from different niches and habitats (Raikar et al. 2001). These studies showed that the responses to temperature could well be species-specific. In addition, short term temperature rise as a form of stress could elevate halocarbon production rate (Laturnus et al. 2000; Abrahamsson et al. 2003).

\section{$3.4 \mathrm{pH}$}

Haloperoxidase activity has a clear association with the production of halocarbons (Wever and van der Horst 2013; Punitha et al. 2017; see also Introduction). A wide range of pH values of between 4 to 8.3 has been reported as an optimum range for haloperoxidase activities, while deviation from the optimal pH range adversely affects enzyme performance (Baden and Corbett 1980; Krenn et al. 1987; Punitha et al. 2017). 
The effect of seawater $\mathrm{pH}$ on halocarbon emissions has been reported for several sub-tropical and tropical seaweed species (Mtolera et al. 1996; Mithoo-Singh et al. 2017). Both studies altered the seawater $\mathrm{pH}$ using the acid/base titration method. Mithoo-Singh et al. (2017) reported that increasing and decreasing $\mathrm{pH}$ from the ambient seawater $\mathrm{pH}$ of 7.8 triggered enhanced emission of halocarbons by the mass-cultivated seaweed, Kappaphycus alvarezii. While testing pH values of 7.2, 7.4, 7.6 and 8.0 against $\mathrm{pH} 7.8$, the lower seawater $\mathrm{pH}$ values of 7.2 and 7.4 enhanced emissions of halocarbons including $\mathrm{CH}_{3} \mathrm{I}$ by Sargassum siliquosum and Padina australis, though with varied enhancement levels between $200 \%$ to $1500 \%$ (Mithoo-Singh et al. 2017). Mtolera et al. (1996) demonstrated increased emissions of $\mathrm{CHBr}_{3}, \mathrm{CH}_{2} \mathrm{I}_{2}, \mathrm{CHBr}_{2} \mathrm{Cl}, \mathrm{C}_{2} \mathrm{Cl}_{4}$ when $\mathrm{pH}$ was increased from 8.0 to 8.8 with Eucheuma denticulatum, at a irradiance level of $1500 \mu$ mol photon $\mathrm{m}^{-2} \mathrm{~s}^{-1}$. At lower irradiance of 400 $\mu$ mol photon $\mathrm{m}^{-2} \mathrm{~s}^{-1}$, the emissions of $\mathrm{CHBr}_{3}, \mathrm{C}_{2} \mathrm{Cl}_{4}$ and $\mathrm{CHBr}_{2} \mathrm{Cl}$ decreased when $\mathrm{pH}$ was increased from 8.0 to 8.8 . The decreased levels of halocarbons were comparable to algae cultivated at optimal condition, where halocarbon emission was observed (Mtolera et al. 1996). The authors suggested that high irradiance and $\mathrm{pH}$ induces $\mathrm{H}_{2} \mathrm{O}_{2}$ formation which leads to the production of halocarbons by haloperoxidases in this seaweed (Mtolera et al. 1996; Table 2 Study 35), while the reason behind the decreasing trend at lower irradiance is unclear.

Increasing levels of $\mathrm{pCO}_{2}$ have recently been found to increase iodine accumulation through the alleviation of oxidative stress for several kelp and other coastal seaweeds, including cultivated Saccharina japonica, in China (Xu et al. 2019). This study, done in the laboratory and in situ mesocosms, also indicated a down-regulation of genes for vanadium-dependant haloperoxidases with increasing $\mathrm{pCO}_{2}$. The increase in accumulation of iodine in coastal seaweed species and their grazers, plus down-regulation of haloperoxidases could affect the global biogeochemical iodine cycle and iodocarbon pool in coastal ecosystems as ocean acidification advances. However, at the time of writing, there has been no direct research on how increasing $\mathrm{pCO}_{2}$ affects halocarbon emission by seaweeds, except for the effect of changing $\mathrm{pH}$ adjusted by acid-base titration method (Mtolera et al. 1996; Mithoo-Singh et al. 2017). In the case of phytoplankton, mesocosm studies have found no distinct effects of ocean acidification on the emission of halocarbons (Hopkins et al. 2010; Hopkins et al. 2013; Webb et al. 2016).

\subsection{Desiccation}

Studies on how seaweed desiccation affects halocarbon emissions by seaweeds have been carried out to better understand the response of seaweeds to tidal changes (Bravo-Linares et al. 2010). They are also highly relevant in determining the contribution of farmed seaweeds towards the emission of halocarbon as industrial-scale processing usually includes a drying process (Leedham Elvidge et al. 
2015). Generally, there is some agreement that the emission of halocarbons by seaweeds is influenced by desiccation perhaps due to easing the seaweed-to-air gas transfer process in the initial stages of the desiccation process by removal of the aqueous phase.

Three studies on halocarbon emission by seaweeds have attempted to simulate natural tidal change experimentally. Nightingale et al. (1995) found increased emissions of $\mathrm{CHBr}_{3}, \mathrm{CH}_{2} \mathrm{Br}_{2}, \mathrm{CH}_{3} \mathrm{I}$, $\mathrm{CHCl}_{3}$ and $\mathrm{CHBr}_{2} \mathrm{Cl}$ from the temperate brown seaweed Ascophyllum nodosum upon re-immersion in seawater after desiccation for 6 hours in the light compared to seaweed that had been immersed in seawater for the same period (Table 2 Study 41). In a similar study using the same approach, the total brominated halocarbons emitted by the same species decreased with 2, 4 and 6 hours desiccation (Bravo-Linares et al. 2010; Fig. 2 Study 41). L. digitata, which was collected from the deepest tidal zone, however, showed increased emission of iodinated halocarbons with increasing period of desiccation (Bravo-Linares et al. 2010; Table 2 Study 44).

A third study measured the release of halocarbons from two temperate seaweed species during exposure to air. The initial desiccation period saw a rapid increase in $\mathrm{CHBr}_{3}$ and $\mathrm{CH}_{2} \mathrm{Br}_{2}$, though this flattened out or decreased within $1-3 \mathrm{hrs}$. This was attributed to the volatilisation of preformed halocarbons near the seaweed surface rather than a physiological response. To simulate rainfall in the environment, the desiccated seaweeds were then rewetted with freshwater and again, an increase in the emissions of these halogenated compounds from both Fucus vesiculosus and Ulva intestinalis was recorded (Leedham Elvidge et al. 2015; Table 2 Study 43 and 45).

In addition to the responses of the seaweeds towards desiccation and resubmersion in terms of halocarbon emission (Nightingale et al. 1995; Bravo-Linares et al. 2010; Leedham Eldvidge et al. 2015), transport of halocarbons emitted by seaweeds to the atmosphere could vary at different tidal levels, due to the presence or absence of a water phase. A study of halocarbon flux from a seagrass meadow found that air exposure, together with tidal change (tidal ebb and flood), produced the highest emission of up to $130 \mathrm{nmol} \mathrm{m}^{-2} \mathrm{hr}^{-1}$ for $\mathrm{CH}_{3} \mathrm{Br}$. In their second campaign, highest fluxes of $\mathrm{CH}_{3} \mathrm{Br}, \mathrm{CH}_{3} \mathrm{Cl}, \mathrm{CH}_{3} \mathrm{I}, \mathrm{CHBr}_{3}$ were also recorded during incoming tide and ebb flow (Weinberg et al. 2015). These results suggest that re-immersion due to the flood tide might also increase the emission of halocarbons from seaweeds compared to continuous air exposure..

\subsection{Nutrient levels and salinity}

Laturnus et al. (2000) found enhanced halocarbon emissions in non-enriched as opposed to Provasolienriched seawater, during a short term (24 hours) and a long term ( 2 months) tests. Provasoli-enriched seawater is a salt water medium containing micronutrients such as vitamins and metal solutions. The 
emission rates of $\mathrm{CH}_{2} \mathrm{ClI}, \mathrm{CH}_{2} \mathrm{I}_{2}$ and $\mathrm{CHBr}_{3}$ by the polar brown seaweed Gymnogongrus antarcticus, were all higher in the longer term exposure to the non-enriched medium compared to the short-term (24 hours) exposure in the same medium.

Sessile intertidal seaweeds are especially susceptible to salinity changes that lead to hyperand hyposaline conditions during evaporation, snow, and rain events. However, when compared with sub-littoral seaweeds the intertidal seaweeds are expected to have higher tolerance and survival rates with respect to salinity changes. Salinity changes affects photosynthetic activity in seaweeds, and to a lesser extent, respiration (Wong and Chang, 2000; Tropin et al. 2003). Hypersaline conditions could induce the formation of reactive oxygen species, as observed in Ulva fasciata, where upregulation of several antioxidants including superoxide dismutase was seen (Sung et al. 2009). These could lead to increased emission of halocarbon by the seaweeds (See Introduction and Photosynthesis).

Increased emission of several iodinated halocarbon compounds including $\mathrm{CH}_{2} \mathrm{I}_{2}$ (Table 2 Study 48) has been reported for the polar red seaweed Gymnogongrus antarcticus at a salinity of 27 psu compared to $34 \mathrm{psu}$. Emissions from seaweeds exposed to a 2-month period (longer term exposure) of low salinity were higher after a $24 \mathrm{~h}$ incubation than those from a $24 \mathrm{~h}$ exposure (shorter term exposure) (Laturnus et al. 2000).

Although a burst of halocarbon emission was reported upon rewetting seaweeds with freshwater post desiccation (see Desiccation section above), there remain many unknowns concerning the effect of freshwater on the emission of halocarbons by seaweeds. In line with the increased risk of increasingly heavy precipitation in the future (IPCC, 2018), dedicated studies on the effect of salinity fluctuations on halocarbon emissions by seaweeds, especially in their natural coastal environment should be intensified. This could bridge the gap in the uncertainties in the halocarbon emission of seaweeds towards salinity change in different regions.

\section{Discussion}

Most of the studies investigating the effect of environmental factors on seaweed halocarbon emission mentioned in this paper were based on single-factor laboratory incubation studies. The seaweeds were normally exposed to the treatment condition, over a range of treatment duration from between 30 minutes (Weinberger et al. 2007; Study 3 and 4) up to 2-3 months (Laturnus et al. 1998; Laturnus et al. 2000). While it is important for environmental factors to be controlled to focus on the effect of one, it is also important for multiple factors to be incorporated into the studies in view of potential interactive effects e.g. synergistic and antagonistic, of the factors under natural environmental conditions, on the halocarbon emission by the seaweeds. Short term exposure of few hours or few 
months to treatments such as irradiance and temperature, could provide an understanding on halocarbon emission of the seaweeds as influenced by the daily diurnal and seasonal changes respectively. Even at these treatment durations, difference in the emission trends displayed by the seaweeds were observed (Manley and Barbero, 2001; Laturnus et al. 2000; Laturnus et al. 2010). There is currently no published data from studies that expose seaweeds to environmental change factor(s) for durations longer than three months. This could likely be due to the challenge of maintaining the seaweed culture over a long term period, due to their viability under laboratory conditions; as unlike phytoplankton, seaweeds have longer generation times. Only few commercial seaweeds are successfully maintained under these conditions. Also, the maintenance of such studies that could last over several years covering the entire life-cycle of the seaweed, may be prohibitive in terms of cost and other resources. It is nevertheless imperative to have such data for prediction of future contribution of halocarbons from the seaweeds. Long-term exposure studies will allow the processes of biological adaptation to climate change, that results in phenotypic and genotypic changes, to be determined. Standardisation of protocols, including standard exposure time for short, medium and long term incubation; use of standardized emission unit; providing seaweed dry weight to fresh weight ratio to enable conversion of emission rates, etc., would enable a better comparison between the emission rates determined from the various studies.

Future climate change may increase the stratospheric load of VSLH compounds (Dessens et al. 2009; Hossaini et al. 2012). Model-based data on sea surface salinity, temperature, wind speed and sea level pressure from year $1979-2100$, has predicted that the emission of halocarbons, particularly $\mathrm{CHBr}_{3}, \mathrm{CH}_{2} \mathrm{Br}_{2}$ and $\mathrm{CH}_{3} \mathrm{I}$, could increase by as much as $29.4 \%, 23.3 \%$ and $5.5 \%$ respectively the under RCP8.5 future climate scenario, and 9\%, 6.4\% and 1.5\% under RCP2.6 (Ziska et al. 2017). However, the effect of future ocean productivity changes could not be ascertained (Ziska et al. 2017). The continuing rapid expansion of the seaweed industry could also contribute to increased stratospheric loading of halogens in a future warmer climate (Hossaini et al. 2012). However, there is currently a lack of accurate data on the standing biomass and productivity of seaweeds, which is important for estimation of halocarbon emissions based on distribution, as well as to predict future changes in seaweed emissions in different regions of the world. Brodie et al. (2014) predicted a shift in seaweed community composition in the event of warming, including kelp forests being wiped out in parts of the northeast Atlantic, and the increase in growth of some of the noncalcifying seaweeds including the red seaweeds Porphyra and Gracilaria (Gao et al.1991; Gao et al.1993) as a result of increased $\mathrm{CO}_{2}$. Such major changes in seaweed distribution could affect the regional and even the global contribution of seaweeds to the halocarbon pool. Our compiled data in Table 2 and Fig. 1 also highlights the lack of data input from genetically diverse populations especially regions from outside of the United Kingdom and neighboring cold-temperate European 
seas i.e. tropics and sub-tropics. This is a critical gap as the tropics and the sub-tropics have been identified as potentially important regions for halocarbon emissions and vertical transport to the upper troposphere/ lower stratosphere (Quack and Wallace, 2003; Hossaini et al. 2012; Tegtmeier et al. 2012; Ziska et al. 2013). Many uncertainties exist in future environmental changes and the potential for alteration in the abundance and distribution of marine sources of halocarbons (Ziska et al. 2017). Integration of seaweed geographical mapping and their halocarbon details are needed to provide an overview of current contribution in halocarbon by the seaweeds in order to predict how the emission trends will be affected in the future.

The IPCC have predicted a decrease in seawater $\mathrm{pH}$ ranging from 0.14 to 0.43 under Representative Concentration Pathways RCP2.6 and RCP8.5 respectively due to the increasing amount of dissolved inorganic carbon (DIC) in seawater (Hoegh-Guldberg et al. 2014). The RCP pathways have been developed based on the predicted trajectory concentrations of greenhouse gases emitted and represent the scenarios of radiative forcing in the range of 2.6 to $8.5 \mathrm{Wm}^{-2}$ for the year 2100 (van Vuuren et al. 2011). Projected increases in $\mathrm{pCO}_{2}$ levels in the future ocean would increase corrosiveness in the shallower coastal regions, affecting mineralisation processes by the coastal microbial community and thereby potentially altering nutrient availability, affecting photosynthesis and growth of the seaweeds (Satoh et al. 2007; Wood et al. 2009, Gordillo, 2012). These indirectly affect halocarbon emission by the seaweeds. Increased nutrient levels could stimulate growth of seaweeds in the coastal region, but cascading effects of increased nutrient level may eventually decrease seaweed biomass due to reduced light penetration and a decline in oxygen level (Rabalais et al. 2009). The single study on polar seaweeds mentioned (see Nutrient levels and salinity) indicates that increased nutrient levels in seawater might not increase the emission of halocarbon by seaweeds. However, this could either be offset by the increase in seaweed biomass therefore increasing localized if not regional contribution of halocarbon by the seaweeds, or decreasing the contribution by seaweeds due to the cascading effects of increased nutrient levels. The same results differed from an in situ measurement on temperate phytoplankton community which showed increased halocarbon emissions due to nutrient-upwelling (Quack et al. 2007; Carpenter et al. 2009; Raimund et al. 2011; Hepach et al. 2014; Hepach et al. 2015). Lack of data input such as this often hinders the understanding of seaweed contribution for the global estimates of current and future climate scenario. More data input from different geographical region as well as further research to give greater insight into future environmental change and for the incorporation for in-situ studies. This is important given that further coastal eutrophication is predicted with global climate change scenarios (Durack et al. 2012; Hoegh-Guldberg et al. 2018). This could affect community composition, biomass and cellular level nutrient uptake and assimilation by seaweeds. 
Global climate change also leads to salinity change. A global mean sea level rise of $0.26-0.77 \mathrm{~m}$ relative to $1986-2005$ is expected with the increase of $1.5^{\circ} \mathrm{C}$ in the next decade or so (IPCC, 2018). Regions at higher latitudes could experience a decrease in seawater salinity as a result of glacier and sea ice melting, while other regions could see an increase in salinity due to increased episodes of evaporation (Durack et al. 2012; Hoegh-Guldberg et al. 2018). Episode of desiccation in seaweeds, as well as re-submersion in seawater or freshwater after a period of desiccation results in increased emission of halocarbon by the seaweeds. It is interesting to note that rain (Ho et al. 2004) can enhance the air-sea gas exchange process and it has been suggested that short and intense rainfall could accelerate gas exchange in the ocean, affecting subsequent sea-air halocarbon transport. On the other hand, kelp beds could contribute to aerosol formation during low tide. According to Küpper et al. (2008), iodide, and to a lesser extent, iodocarbons ((Küpper et al. 2011), released by seaweed such as Laminaria digitata during low tide was able to scavenge atmospheric ozone, leading to the formation molecular iodine, which can then go on to be involved in aerosol formation. This is supported by observations of particle bursts over kelp beds during daytime low tides. Studies such as these will be useful in refining predictions of future coastal halogen loads in the event of higher evaporation and precipitation due to climate-related temperature rise, and related changes to water density such as seawater salinity (Hoegh-Guldberg et al. 2018).

\section{Summary and Conclusion}

Changes in the environment, for example irradiance and temperature, will affect the emission of halocarbons by seaweeds. The responses of seaweeds towards these changes are very likely speciesand compound-specific. While the halocarbon emission responses of seaweeds towards the changes in the environmental parameters have been documented, there is still no clear picture of what the future holds. It has been predicted that global climate change and ocean acidification will affect the distribution, abundance and diversity of seaweeds in the future through changes in the marine environment and this could also influence where seaweeds could be farmed.

The latest Intergovernmental Panel on Climate Change (IPCC) reported an expected average rise in temperature of $1.5^{\circ} \mathrm{C}$ in the period $2030-2052$ based on the current warming rate, accompanied by a global mean sea level rise (IPCC, 2018). Greater warming is expected in the Arctic $\left(3^{\circ} \mathrm{C}-4.5^{\circ} \mathrm{C}\right.$ of regional warming $)$, and on land $\left(>1.5^{\circ} \mathrm{C}\right)$ rather than in water $\left(<1.5^{\circ} \mathrm{C}\right)$. This will also manifest in short-term extreme weather events such as hurricanes and cyclones and changes in seawater salinity (Durack et al. 2012; Hoegh-Guldberg et al. 2018). These could bring about changes in seawater chemistry thereby affecting seaweed physiology and growth responses. It creates many unknowns concerning how these changes could affect the halocarbon emissions by seaweeds. In addition, environmental changes affecting plankton blooms and the seaweeds themselves could 
contribute to significant compositional and molecular changes in dissolved organic matter (Thornton, 2014; Zark et al. 2015). This could in turn affects halocarbon emission by the seaweeds (Lin and Manley, 2012; Liu et al. 2015).

On the basis of the current published evidence, we suggest the following research gaps are targeted for further research:

i. Research encompassing diurnal and seasonal variations in environmental factors as well as studies that involves longer exposure period to environmental change to provide insights into biological adaptation of seaweeds in terms of halocarbon emissions.

ii. Establish multiple factor studies to determine the interactive effects of environmental change on halocarbon emission by the seaweeds.

iii. A more standardized approach for easy comparison between studies from different authors.

iv. Lack of data on standing biomass (crop) as well as halocarbon studies of seaweeds from different geographical locations and identification of the key/dominant seaweed species in specific habitats. This gap could benefit from the integration of remote sensing techniques.

v. A concerted international level approach to uncover whether there are consistent geographical differences amongst seaweed species from temperate, tropical and polar areas, and whether the zone of collection alters the halocarbon emission responses of seaweeds towards irradiance. If differences were uncovered it would point to a need to further investigate variation in underlying physiology and mechanism of halocarbon production by seaweeds.

In conclusion, more insights into the factors affecting the production and emission of the volatile halocarbon compounds by the seaweeds are needed. It will be important to include the interaction of multiple stress factors in future studies (Boyd et al. 2018), in order to build a more comprehensive understanding of what is happening now and to better evaluate the effect of climate change on halocarbon emission by seaweeds in the future. The Earth system is highly complex, comprising organisms, oceans, abiotic factors, weather systems, and atmospheric composition. Due to the interactions between the biotic and abiotic parts of the system, one might ponder how the changes to the system, happening together and at unprecedented pace, will affect the emission of halocarbons by the seaweeds. 


\section{References}

Abrahamsson K, Choo KS, Pedersen M, Johansson G, Snoeijs P (2003) Effects of temperature on the production of hydrogen peroxide and volatile halocarbons by brackish water algae. Phytochemistry 6:725-734.

Almeida M, Filipe S, Humanes M, Maia MF, Melo R, Severino N, da Silva JA, Frausto da Silva JJ, Wever R (2001) Vanadium haloperoxidases from brown algae of the Laminariaceae family. Phytochemistry 57:633-642.

Amachi S, Kamagata Y, Kanagawa T, Muramatsu Y (2006) Bacteria mediate methylation of iodine in marine and terrestrial environments. Applied and Environmental Microbiology 67:27182722.

Amsler CD (2008) Algal Chemical Ecology. 249-255. Springer-Verlag, Berlin Heidelberg, pp 249_ 255

Baden DG, Corbett MD (1980) Bromoperoxidases from Penicillus capitatus, Penicillus lamourouxii and Rhipocephalus phoenix. Biochemical Journal 187(1):205-211.

Baker JM, Sturges WT, Sugier J, Sunnenberg G, Lovett AA, Reeves CE, Nightingale PD, Penkett SA (2001) Emissions of $\mathrm{CH}_{3} \mathrm{Br}$, organochlorines, and organoiodines from temperate macroalgae. Chemosphere 3:93-106.

Birben E, Sahiner UM, Sackesen C, Erzurum S, Kalayci O (2012) Oxidative stress and antioxidant defense. The World Allergy Organization Journal 5(1):9-19.

Bischof K, Gómez I, Molis M, Hanelt D, Karsten U, Lüder U, Roleda MY, Zacher K, Wiencke C (2006) Ultraviolet radiation shapes seaweed communities. Reviews in Environmental Science and Bio/Technology 5:141-166.

Bischof K, Hanelt D, Tüg H, Karsten U, Brouwer PEM, Wiencke C (1998) Acclimation of brown algal photosynthesis to ultraviolet radiation in Arctic coastal waters (Spitsbergen, Norway). Polar Biology 20:388-395.

Björn LO, Callaghan TV, Gehrke C, Johanson U, Sonesson M (1999) Ozone depletion, ultraviolet radiation and plant life. Chemosphere - Global Change Science 1(4):449-454.

Boyd P W, Collins S, Dupont S, Fabricius K, Gattuso JP, Havenhand J, Hutchins DA, Riebesell U, Rintoul MS, Vichi M (2018) Experimental strategies to assess the biological ramifications of multiple drivers of global ocean change-A review. Global Change Biology 24(6):22392261.

Bravo-Linares CM, Mudge SM, Loyola-Sepulveda RH (2010) Production of volatile organic compounds (VOCs) by temperate macroalgae. The use of solid phase microextraction (SPME) coupled to GC-MS as method of analysis. Journal of the Chilean Chemical Society 55(2):227-332. 
Brodie J, Williamson CJ, Smale DA, Kamenos NA, Mieszkowska N, Santos R, Cunliffe M, Steinke M, Yesson C, Anderson KM, Asnaghi V, Brownlee C, Burdett H, Burrows MT, Collins S, Donohue PJC, Harvey B, Foggo A, Noisette F, Nunes J, Ragazzola F, Raven JA, Schmidt DN, Suggett D, Teichberg M, Hall-Spencer JM (2014) The future of the northeast Atlantic benthic flora in a high $\mathrm{CO}_{2}$ world. Ecology and Evolution 4(13):2787-2798.

Butler JH, King DB, Lobert JM, Montzka SA, Yvon-Lewis SA, Hall BD, Warwick NJ, Mondeel DJ, Aydin N, Ellkins JW (2007) Oceanic distributions and emissions of short-lived halocarbons. Global Biogeochemical Cycles 21:GB1023.

Carpenter LJ, Archer SD, Beale R (2012) Ocean-atmosphere trace gas exchange. Chemical Society Reviews 41: 6473-6506.

Carpenter LJ, Jones CE, Dunk RM, Hornsby KE, Woeltjen J (2009) Air-sea fluxes of biogenic bromine from the tropical and North Atlantic Ocean. Atmospheric Chemistry and Physics 9:1805-1816.

Carpenter LJ, Malin G, Liss PS, Küpper FC (2000). Novel biogenic iodine-containing trihalomethanes and other short-lived halocarbons in the coastal East Atlantic. Global Biogeochemical Cycles 14(4):1191-1204.

Carpenter LJ, Reimann S, Burkholder JB, Clerbaux C, Hall BD, Hossaini R, Laube JC, Yvon-Lewis SA (2014) Ozone-depleting substances (ODSs) and other gases of interest to the Montreal protocol. In: Scientific Assessment of Ozone Depletion: 2014, Global Ozone Research and Monitoring Project-Report No.55. World Meteorological Organization, Geneva, Switzerland.

Chance R, Baker AR, Küpper FC, Hughes C, Kloareg B, Malin G (2009) Release and transformations of inorganic iodine by marine macroalgae. Estuarine, Coastal and Shelf Science 82:406-414.

Chipperfield MP, Pyle JA (1998) Model sensitivity studies of Arctic ozone depletion. Journal of Geophysical Research 103:28389-28403.

Collén J, Ekdahl A, Abrahamsson K, Pédersen M (1994) The involvement of hydrogen peroxide in the production of volatile halogenated compounds by Meristiella gelidium. Phytochemistry 36(5):1197-1202.

Collén J, Jimenez del Rio M, Garcia-Reina G, Pédersen M (1995) Photosynthetic production of hydrogen peroxide by Ulva rigida C. Ag. (Chlorophyta). Planta 196:225-230.

Collén J, Pedersén M (1999) Production, scavenging and toxicity of hydrogen peroxide in the green seaweed Ulva rigida. European Journal of Phycology 31:265-271.

Colvard NB, Carrington E, Helmuth B (2014) Temperature-dependent photosynthesis in the intertidal alga Fucus gardneri and sensitivity to ongoing climate change. Journal of Experimental Marine Biology and Ecology 458:6-12. 
Daniel JS, Solomon S, Portmann RW, Garcia RR (1999). Stratospheric ozone destruction: The importance of bromine relative to chlorine. Journal of Geophysical Research 104 (D19):23871-23880.

de Bettignies T, Wernberg T, Gurgel CFD (2018). Exploring the influence of temperature on aspects of the reproductive phenology of temperate seaweeds. Frontiers in Marine Science 5(218):18.

de Oliveira LS, Tschoeke DA, Magalhães Lopes ACR, Sudatti DB, Meirelles PM, Thompson CC, Pereira RC, Thompson FL (2017). Molecular mechanisms for microbe recognition and defense by the red seaweed Laurencia dendroidea. mSphere 2:e00094-17.

Dessens O, Zeng G, Warwick N, Pyle J (2009) Short-lived bromine compounds in the lower stratosphere; impact of climate change on ozone. Atmospheric Science Letter 10:201-206.

Dietz KJ (2016) Thiol-based peroxidases and ascorbate peroxidases: Why plants rely on multiple peroxidase systems in the photosynthesizing chloroplast? Molecules and Cells 39(1):20-25.

Dummermuth AL, Karsten U, Fisch KM, König GM, Wiencke C (2003) Responses of marine macroalgae to hydrogen-peroxide stress. Journal of Experimental Marine Biology and Ecology 289:103-121.

Durack PJ, Wijffels SE, Matear RJ (2012). Ocean salinities reveal strong global water cycle intensification during 1950 to 2000. Science 336(6080): 455-458.

Ekdahl A, Pédersen M, Abrahamsson K (1998) A study of the diurnal variation of biogenic volatile halocarbons. Marine Chemistry 63:1-8.

FAO (2018) The global status of seaweed production, trade and utilization. Globefish Research Programme 124.

Figueroa FL, Korbee N, Carrillo P, Medina-Sánchez JM, Mata MT, Bonomi J, Sánchez-Castillo PM (2009) The effects of UV radiation on photosynthesis estimated as chlorophyll fluorescence in Zygnemopsis decussata (Chlorophyta) growing in a high mountain lake (Sierra Nevada, Southern Spain). Journal of Limnology 68:206-216.Fuhlbrügge S, Quack B, Tegtmeier S, Atlas E, Hepach H, Shi Q, Raimund S, Krüger K (2016) The contribution of oceanic halocarbons to marine and free tropospheric air over the tropical West Pacific. Atmospheric Chemistry and Physics 16:7569-7585.

Gao K, Aruga Y, Asada K, Ishihara T, Akano T, Kiyohara, M (1991) Enhanced growth of the red alga Porphyra yezoensis Ueda in high $\mathrm{CO}_{2}$ concentration. Journal of Applied Phycology 3:355362.

Gao K, Aruga Y, Asada K, Kiyohara M (1993) Influence of enhanced $\mathrm{CO}_{2}$ on growth and photosynthesis of the red algae Gracilaria sp. and G. chilensis. Journal of Applied Phycology 5:563-571. 
Goodwin KD, North WJ, Lidstrom ME (1997) Production of bromoform and dibromomethane by

Giant Kelp: Factors affecting release and comparison to anthropogenic bromine sources.

Limnology and Oceanography 42:1725-1734.

Gordillo FJL (2012) Environment and algal nutrition. In: Wiencke C and Bischof K (eds) Seaweed Biology. Springer-Verlag, Berlin, pp 67-86.

Gribble GW (2003) The diversity of naturally produced organohalogens. Chemosphere 52(2):289_ 297.

Hanelt D, Wiencke C, Bischof K (2003) Photosynthesis in Marine Macroalgae. In: Larkum AW, Douglas SE, Raven JA (eds) Advances in Photosynthesis and Respiration. Kluwer Academic, Dordrecht, Germany, pp 413-435.

Harley CDG, Anderson KM, Demes KW, Jorve JP, Kordas RL, Coyle TA, Graham MH (2012) Effects of climate change on global seaweed communities. Journal of Phycology 48:10641078.

Hepach H, Quack B, Raimund S, Fischer T, Atlas EL, Bracher A (2015) Halocarbon emissions and sources in the equatorial Atlantic Cold Tongue. Biogeosciences 12: 6369-6387.

Hepach H, Quack B, Ziska F, Fuhlbrügge S, Atlas EL, Krüger K, Peeken I, Wallace DWR (2014) Drivers of diel and regional variations of halocarbon emissions from the tropical North East Atlantic. Atmospheric Chemistry and Physics 14:1255-1275.

Ho DT, Zappa CJ, McGillis WR, Bliven LF, Ward B, Dacey JWH, Schlosser P, Hendricks MB (2004) Influence of rain on air-sea gas exchange: Lessons from a model ocean. Journal of Geophysical Research 109:C08S18.

Hoegh-Guldberg O, Cai R, Poloczanska ES, Brewer PG, Sundby S, Hilmi K, Fabry VJ, Jung S (2014) The Ocean. In: Barros VR, Field CB, Dokken DJ, Mastrandrea MD, Mach KJ, Bilir TE, Chatterjee M, Ebi KL, Estrada YO, Genova RC, Girma B, Kissel ES, Levy AN, MacCracken S, Mastrandrea PR, White LL (eds) Climate Change 2014: Impacts, Adaptation, and Vulnerability. Part B: Regional Aspects. Contribution of Working Group II to the Fifth Assessment Report of the Intergovernmental Panel on Climate Change. Cambridge University Press, Cambridge and New York, pp 1655-1731.

Hoegh-Guldberg, O, Jacob, D, Taylor, M, Bindi, M, Brown, S, Camilloni, I, Diedhiou, A, Djalante, R, Ebi, K.L, Engelbrecht, F, Guiot, J, Hijioka, Y, Mehrotra, S, Payne, A, Seneviratne, S.I, Thomas, A, Warren, R, Zhou, G, 2018. Impacts of $1.5^{\circ} \mathrm{C}$ global warming on natural and human systems. In: Masson-Delmotte V, Zhai P, Pörtner HO, Roberts D, Skea J, Shukla PR, Pirani A, Moufouma-Okia W, Péan C, Pidcock R, Connors S, Matthews JBR, Chen Y, Zhou X, Gomis MI, Lonnoy E, Maycock T, Tignor M, Waterfield T (eds) Global Warming of $1.5^{\circ} \mathrm{C}$, An IPCC Special Report on the Impacts of Global Warming of $1.5^{\circ} \mathrm{C}$ Above Preindustrial Levels and Related Global Greenhouse Gas Emission Pathways, in the Context of 
Strengthening the Global Response to the Threat of Climate Change, Sustainable Development, and Efforts to Eradicate Poverty. In Press.

Hopkins FE, Kimmance SA, Stephens JA, Bellerby RGJ, Brussaard CPD, Czerny J, Schulz KG, Archer SD, (2013) Response of halocarbons to ocean acidification in the Arctic.

Biogeosciences 10:2331-2345.

Hopkins FE, Turner SM, Nightingale PD, Steinke M, Bakker D, Liss PS (2010) Ocean acidification and marine trace gas emissions. Proceedings of the National Academy of Sciences of the United States of America 107(2):760-765.

Hossaini R, Chipperfield MP, Dhomse S, Ordonez C, Saiz-Lopez A, Abraham NL, Archibald A, Braesicke P, Telford P, Warwick N, Yang X, Pyle J (2012) Modelling future changes to the stratospheric source gas injection of biogenic bromocarbons. Geophysical Research Letters 39:L20813.

Hossaini R, Chipperfield MP, Montzka SA, Rap A, Dhomse S, Feng W (2015) Efficiency of shortlived halogens at influencing climate through depletion of stratospheric ozone. Nature Geoscience 8(3):186-190. doi:10.1038/ngeo2363

Hossaini R, Patra PK, Leeson AA, Krysztofiak G, Abraham NL, Andrews SJ, Archibald AT, Aschmann J, Atlas EL, Belikov DA, Bönisch H, Carpenter LJ, Dhomse S, Dorf M, Engel A, Feng W, Fuhlbrügge S, Griffiths PT, Harris NRP, Hommel R, Keber T, Krüger K, Lennartz ST, Maksyutov S, Mantle H, Mills GP, Miller B, Montzka SA, Moore F, Navarro MA, Oram DE, Pfeilsticker K, Pyle JA, QuackB, Robinson AD, Saikawa E, Saiz-Lopez A, Sala S, Sinnhuber BM, Taguchi S, Tegtmeier S, Lid- ster R. T, Wilson C, Ziska F (2016) A multimodel intercomparison of halogenated very short-lived substances (TransCom- VSLS): linking oceanic emissions and tropospheric transport for a reconciled estimate of the stratospheric source gas injection of bromine. Atmospheric Chemistry and Physics 16:91639187.

Hughes C, Malin G, Nightingale PD, Liss PS (2006) The effect of light stress on the release of volatile iodocarbons by three species of marine microalgae. Limnology and Oceanography 51(6):2849-2854.

IPCC (2018) Summary for Policymakers. In: Masson-Delmotte V, Zhai P, Pörtner HO, Roberts D, Skea J, Shukla PR, Pirani A, Moufouma-Okia W, Péan C, Pidcock R, Connors S, Matthews JBR, Chen Y, Zhou X, Gomis MI, Lonnoy E, Maycock T, Tignor M, Waterfield T(eds) Global warming of $1.5^{\circ} \mathrm{C}$. An IPCC Special Report on the impacts of global warming of $1.5^{\circ} \mathrm{C}$ above pre-industrial levels and related global greenhouse gas emission pathways, in the context of strengthening the global response to the threat of climate change, sustainable development, and efforts to eradicate poverty. World Meteorological Organization, Geneva, Switzerland. 
Kalle K (1971) Salinity: general introduction. In: Kinne O (ed) Marine Ecology (Vol 1). Wiley, New York, pp 683-688.

Keng FSL, Phang SM, Abd Rahman N, Leedham EC, Hughes C, Robinson AD, Harris NRP, Pyle JA, Sturges, WT (2013) Volatile halocarbon emissions by three tropical brown seaweeds under different irradiances. Journal of Applied Phycology 25(5):1377-1386.

Kessler A, Baldwin IT (2002) Plant responses to insect herbivory: the emerging molecular analysis. Annual Review of Plant Biology 53:299-328.

Krenn BE, Plat H, Wever R (1987) The bromoperoxidase from the red alga Ceramium rubrum also contains vanadium as a prosthetic group. Biochimica et Biophysica Acta Protein Structure and Molecular Enzymology 912(2):287-291.

Küpper FC, Carpenter LJ, Leblanc C, Toyama C, Uchida Y, Maskrey BJ, Robinson J, Verhaeghe EF, Malin G, Luther III GW, Kroneck PMH, Kloareg B, Meyer-Klaucke W, Muramatsu Y, Megson IK, Potin P, Feiters MC (2013) In vivo speciation studies and antioxidant properties of bromine in Laminaria digitate reinforce the significance of iodine accumulation for kelps. Journal of Experimental Botany 64(10):2653-2664.

Küpper FC, Carpenter LJ, McFiggans GB, Palmer CJ, Waite TJ et al (2008) Iodide accumulation provides kelp with an inorganic antioxidant impacting atmospheric chemistry. Proceedings of the National Academy of Sciences of the United States of America 105:6954-6958.

Küpper FC, Feiters MC, Olofsson B, Kaiho T, Yanagida S, Zimmermann MB, Carpenter LJ, Luther III GW, Lu Z, Jonsson M, Kloo L (2011) Commemorating two centuries of iodine research: An interdisciplinary overview of current research. Angewandte Chemie International Edition 50:11598-11620.

Küpper FC, Miller EP, Andrews SJ, Hughes C, Carpenter L J, Meyer-Klaucke W, Toyama C, Muramatsu Y, Feiters MC, Carrano CJ (2018) Emission of volatile halogenated compounds, speciation and localization of bromine and iodine in the brown algal genome model Ectocarpus siliculosus. JBIC Journal of Biological Inorganic Chemistry. doi:10.1007/s00775018-1539-7

Küpper FC, Müller DG, Peters AF, Kloareg B, Potin P (2002) Oligoalginate recognition and oxidative burst play a key role in natural and induced resistance of sporophytes of Laminariales. Journal of Chemical Ecology 28:2057-2081.

Küpper FC, Schweigert N, Ar Gall E, Legendre JM, Vilter H, Kloareg B (1998) Iodine uptake in Laminariales involves extracellular, haloperoxidase-mediated oxidation of iodide. Planta 207:163-171.

Laturnus F (1995) Release of volatile halogenated organic compounds by unialgal cultures of polar macroalgae. Chemosphere 31(6):3387 - 3395. 
Laturnus F (2001) Marine macroalgae in polar regions as natural sources for volatile organohalogens. Environmental Science and Pollution Research 8(2):103-108.

Laturnus F, Giese B, Wiencke C, Adams FC (2000) Low-molecular-weight organoiodine and organobromine compounds released by polar macroalgae - The influence of abiotic factors. Fresenius Journal of Analytical Chemistry 368:297-302.

Laturnus F, Svensson T, Wiencke C (2010) Release of reactive organic halogens by the brown macroalga Saccharina latissima after exposure to ultraviolet radiation. Polar Research 29:379-384.

Laturnus F, Wiencke C, Adams FC (1998) Influence of light conditions on the release of volatile halocarbons by Antarctic macroalgae. Marine Environmental Research 45(3):285-294.

Leedham EC, Hughes C, Keng FSL, Phang SM, Malin G, Sturges WT (2013) Emission of atmospherically significant halocarbons by naturally occurring and farmed tropical macroalgae, Biogeosciences 10(6):3615-3633.

Leedham Elvidge EC, Phang SM, Sturges WT, Malin G (2015) The effect of desiccation on the emission of volatile bromocarbons from two common temperate macroalgae. Biogeosciences Discussions 11:10673-10701.

Liang Q, Atlas E, Blake D, Dorf M, Pfeilsticker K, Schauffler S (2014) Convective transport of veryshort-lived bromocarbons to the stratosphere. Atmospheric Chemistry and Physics 14:57815792.

Liang Q, Stolarski RS, Kawa SR, Nielse JE, Rodriguez JM, Douglass AR, Rodriguez JM, Blake DR, Atlas EL, Ott LE (2010) Finding the missing stratospheric Bry: A global modeling study of $\mathrm{CHBr}_{3}$ and $\mathrm{CH}_{2} \mathrm{Br}_{2}$. Atmospheric Chemistry and Physics 10(5):2269-2286.

Lin CY, Manley SL (2012) Bromoform production from seawater treated with bromoperoxidase. Limnology and Oceanography 57(6):1857-1866.

Liu Y, Thornton DCO, Bianchi TS, Arnold WA, Shields MR, Chen J, Yvon-Lewis SA (2015). Dissolved Organic Matter Composition Drives the Marine Production of Brominated Very Short-Lived Substances. Environmental Science and Technology 49:3366-3374.

Lobban CS, Harrison PJ (1997) Seaweed Ecology and Physiology. Cambridge University Press, New York.

Manley SL (2002) Phytogenesis of halomethanes: a product of selection or a metabolic accident? Biogeochemistry 60:163-180.

Manley SL, Barbero PE (2001) Physiological constraints on bromoform $\left(\mathrm{CHBr}_{3}\right)$ production by Ulva lactuca (Chlorophyta). Limnology and Oceanography 46:1392-1399.

Milkova T, Talev G, Christov R, Dimitrova-Konaklieva S, Popov S (1997) Sterols and volatiles in Cystoseira barbata and Cystoseira crinita from the Black Sea. Phytochemistry 45(1):93-95. 
Mithoo-Singh PK, Keng FSL, Phang, SM, Leedham Elvidge EC, Sturges WT, Malin G, Abd Rahman N (2017) Halocarbon emissions by selected tropical seaweeds, species-specific and compound-specific responses under changing pH. PeerJ 5:e2918.

Manley SL (2002) Phytogenesis of halomethanes: A product of selection or a metabolic accident? Biogeochemistry 60:163-180.

McMurry J (2008) Organic Chemistry $7^{\text {th }}$ Ed. Thompson Brooks/Cole, Belmont, CA.

Mtolera MSO, Collén J, Pedersén M, Ekdahl A, Abrahamsson K, Semesi AK (1996) Stress-induced production of volatile halogenated organic compounds in Eucheuma denticulatum (Rhodophyta) caused by elevated pH and high light intensities. European Journal of Phycology 31(1):89-95.

Neilson AH (2003) Biological effects and biosynthesis of brominated metabolites. In: Neilson AH (ed) The Handbook of Environmental Chemistry vol 3. Springer, Berlin, pp 75- 204

Nightingale PD, Malin G, Liss PS (1995) Production of chloroform and other low-molecular-weight halocarbons by some species of macroalgae. Limnology and Oceanography 40(4):680-689.

Nitschke U, Ruth AA, Dixneuf S, Stengel DB (2011) Molecular iodine emission rates and photosynthetic performance of different thallus parts of Laminaria digitata (Phaeophyceae) during emersion. Planta 233:737-748.

Ohsawa N, Ogata Y, Okada N, Itoh N (2001) Physiological function of bromoperoxidase in the red marine alga, Corallina pilulifera: production of bromoform as an allelochemical and the simultaneous elimination of hydrogen peroxide. Phytochemistry 58:683-692.

Opsahl S, Benner R (1997). Distribution and cycling of terrigenous dissolved organic matter in the ocean. Nature 6:480-482.

Palmer CJ, Anders TL, Carpenter LJ, Küpper FC, McFiggans G (2005) Iodine and halocarbon response of Laminaria digitata to oxidative stress and links to atmospheric new particle production. Environmental Chemistry 2:282-290.

Paul NA, de Nys R, Steinberg PD (2006) Chemical defense against bacteria in the red alga Asparagopsis arnata: linking structure with function. Marine Ecology Progress Series 306:87-101.

Paul C, Pohnert G (2011) Production and role of volatile halogenated compounds from marine algae. Natural Product Reports 28:186-194.

Pedersén M, Collén J, Abrahamsson K, Ekdahl A (1996) Production of halocarbons from seaweeds: an oxidative stress reaction? Scientia Marina 60:255-261.

Phang SM, Keng FSL, Mithoo-Singh PK, Lim YK, Abd Rahman N, Leedham EC, Robinson AD, Harris NRP, Pyle JA, Sturges WT (2015) Can seaweed farming in the tropics contribute to climate change through emission of short-lived halocarbons? Malaysian Journal of Science 34(1):7-18. 
Punitha T, Phang SM, Juan JC, Beardall J (2017) Environmental control of vanadium haloperoxidases and halocarbon emissions in macroalgae. Marine Biotechnology 20(3):282-303.

Quack B, Wallace DWR (2003) Air-sea flux of bromoform: controls, rates and implications. Global Biogeochemical Cycles 17:1023-1050.

Quack B, Atlas E, Petrick G, Wallace DWR (2007) Bromoform and dibromomethane above the mauritanian upwelling: Atmospheric distributions and oceanic emissions. Journal of Geophysical Research Atmospheres 112:D09312.

Rabalais NN, Turner RE, Díaz RJ, Justić D (2009) Global change and eutrophication of coastal waters. ICES Journal of Marine Science 66:1528-1537.

Raimund S, Quack B, Bozec Y, Vernet M, Rossi V, Garçon V, Morel Y, Morin P (2011) Sources of short-lived bromocarbons in the Iberian upwelling system. Biogeosciences 8:1551- 1564 .

Raikar SV, Lima M, Fujita Y (2001) Effect of temperature, salinity and light intensity on the growth of Gracilaria spp. (Gracilariales, Rhodophyta) from Japan, Malaysia and India. Indian Journal of Marine Sciences 30:98-104.

Rutherford AW, Osyczka A, Rappaport F (2012) Back-reactions, short-circuits, leaks and other energy wasteful reactions in biological electron transfer: Redox tuning to survive life in $\mathrm{O}_{2}$. FEBS Letters 586(5):603-616.

Saiz-Lopez A, von Glasow R (2012) Reactive halogen chemistry in the troposphere. Chemical Society Reviews 41:6448-6472. doi:10.1039/c2cs35208gSatoh H, Nakamura Y, Okabe S (2007) Influences of infaunal burrows on the community structure and activity of ammoniaoxidizing bacteria in intertidal sediments. Applied and Environmental Microbiology 73:13411348.

Stemmler I, Hense I, Quack B (2015) Marine sources of bromoform in the global open ocean - global patterns and emissions. Biogeosciences 12:1967-1981.

Stewart RIA, Dossena M, Bohan DA, Jeppesen E, Kordas RL, Ledger ME, Meerhoff M, Moss B, Mulder C, Shurin JB, Suttle B, Thompson R, Trimmer M, Woodward G (2013) Mesocosm experiments as a tool for ecological-climate change research. Advances in Ecological Research 48:71-181.

Sung MS, Hsu YT, Wu TM, Lee TM (2009) Hypersalinity and hydrogen peroxide upregulation of gene expression of antioxidant enzymes in Ulva fasciata against oxidative stress. Marine Biotechnology 11:199-209.

Sundström J, Collén J, Abrahamsson K, Pedersén M (1996) Halocarbon production ad in vivo brominating activity of Eucheuma denticulatum. Phytochemistry 42(6):15527-1530.

Tadaaki B, Muramatsu Y, Amachi S (2006) Rate of iodine volatilization and accumulation by filamentous fungi through laboratory cultures. Chemosphere 65(11):2216-2222. 
Tegtmeier S, Kruger K, Quack B, Atlas EL, Pisso I, Stohl A, Yang X (2012) Emission and transport of bromocarbons: From the west Pacific Ocean into the stratosphere. Atmospheric Chemistry and Physics 12:10633-10648.

Thornton DCO (2014) Dissolved organic matter (DOM) release by phytoplankton in the contemporary and future ocean. European Journal of Phycology 49(1):20-46.

Toda H, Itoh N (2011) Isolation and characterization of gene encoding S-adenosyl-L-methioninedependent halide/thiol methyltransferase (HTMT) from marine diatom Phaeodactylum tricornutum: Biogenic emissions of $\mathrm{CH}_{3} \mathrm{I}$ emissions in oceans. Phytochemistry 72:337-343.

Toth GB, Pavia H (2007) Induced herbivore resistance in seaweeds: a meta-analysis. Journal of Ecology 95:425-434.

Tropin IV, Radzinskaya NV, Voskoboinikov GM (2003) The influence of salinity on the rate of dark respiration and structure of the cells of brown algae thalli from the Barents Sea littoral. Biological Bulletin 30:40-47.

van Vuuren DP, Edmonds J, Kainuma MLT, Riahi K, Thomson A, Matsui T, Hurtt G, Lamarque JF, Meinshausen M, Smith S, Grainer C, Rose S, Hibbard KA, Nakicenovic N, Krey V, Kram T (2011) Representative concentration pathways: An overview. Climatic Change 109:5-31.

Verhaeghe EF, Fraysse A, Guerquin-Kern JL, Wu TD, Devès G et al. (2008) Microchemical imaging of iodine distribution in the brown alga Laminaria digitata suggests a new mechanism for its accumulation. Journal of Biology Inorganic Chemistry 13:257-269.

Webb AL, Leedham Elvidge E, Hughes C, Hopkins FE, Malin G, Bach LT, Schulz K, Crawfurd K, Brussaard CPD, Stuhr A, Riebesell U, Liss PS (2016) Effect of ocean acidification and elevated $\mathrm{fCO}_{2}$ on trace gas production by a Baltic Sea summer phytoplankton community. Biogeosciences 13(15):4595-4613.

Wever R, Tromp MGM, Krenn BE, Marjani A, Van Toi M (1991) Brominating activity of seaweed Ascophyllum nodosum: Impact on the biosphere. Environmental Science and Technology 25:446-449.

Wever R, van der Horst 2013. The role of vanadium haloperoxidases in the formation of volatile brominated compounds and their impact on the environment. Dalton Transactions 42:1177811786.

Weinberg I, Bahlmann E, Eckhardt T, Michaelis W, Seifert R (2015) A halocarbon survey from a seagrass dominated subtropical lagoon, Ria Formosa (Portugal): flux pattern and isotopic composition. Biogeosciences 12:1697-1711.

Weinberger F, Coquempot B, Forner S, Morin P, Kloareq P et al (2007) Different regulation of haloperoxidation during agar oligosaccharide-activated defence mechanisms in two related red algae, Gracilaria sp. and Gracilaria chilensis. Journal of Experimental Botany 58(15/16):4365-4372. 
White AL, Jahnke LS (2002) Contrasting effects of UV-A and UV-B on photosynthesis and photoprotection of b-carotene in two Dunaliella spp. Plant Cell Physiology 43(8):877-884.

Wong SL, Chang J (2000) Salinity and light effects on growth, photosynthesis, and respiration of Grateloupia filicina (Rhodophyta). Aquaculture 182(3-4):387-395.

Wood HL, Widdicombe S, Spicer JI (2009) The influence of hypercapnia and the infaunal brittlestar Amphiura filiformis on sediment nutrient flux - will ocean acidification affect nutrient exchange? Biogeosciences 6:2015-2024.

WMO (World Meteorological Organization) (2018) Scientific Assessment of Ozone Depletion: 2018, Global Ozone Research and Monitoring Project-Report No.58. World Meteorological Organisation, Geneva

Xu D, Brennan G, Xu L, Zhang XW, Fan X, Han WT, Mock T, McMinn A, Hutchins DA, Ye NH (2019) Ocean acidification increases iodine accumulation in kelp-based coastal food webs. Global Change Biology 25(2):629-639.

Xue LG, Zhang Y, Zhang TG, An LZ, Wang XL (2005) Effects of enhanced ultraviolet-b radiation on algae and cyanobacteria. Critical Reviews in Microbiology 31:79-89.

Yamamoto H, Yokouchi Y, Otsuki A, Itoh H (2001) Depth profiles of volatile halogenated hydrocarbons in seawater in the Bay of Bengal. Chemosphere 45(3):371-377.

Yokouchi Y, Ooki A, Hashimoto S, Itoh N (2014) A study on the production and emission of marinederived volatile halocarbons. In: Uematsu M, Yokouchi Y, Watanabe YW, Takeda S, Yamanaka Y (eds) Western Pacific air-sea interaction study. TERRAPUB, Tokyo, pp 1 - 25

Younus H (2018) Therapeutic potentials of superoxide dismutase. International Journal of Health Sciences 12(3):88-93.

Zark M, Riebesell U, Dittmar T (2015) Effects of ocean acidification on marine dissolved organic matter are not detectable over the succession of phytoplankton blooms. Science Advances 1(9):e1500531.

Ziska F, Quack B, Abrahamsson K, Archer SD, Atlas E et al (2013) Global sea-to-air flux climatology for bromoform, dibromomethane and methyl iodide. Atmospheric Chemistry and Physics 13:8915-8934.

Ziska F, Quack B, Tegtmeier S, Stemmler I, Krüger K (2017) Future emissions of marine halogenated very-short lived substances under climate change. Journal of Atmospheric Chemistry 74(2):245-260.

Zou DH, Gao KS (2014) Temperature response of photosynthetic light and carbon-use characteristics in the red seaweed Gracilariopsis lemaneiformis (Gracilariales, Rhodophyta). Journal of Phycology 50:366-375. 
Zou XX, Xing SS, Su X, Zhu J, Huang HQ, Bao SX (2018) The effects of temperature, salinity and irradiance upon the growth of Sargassum polycystum C. Agardh (Phaeophyceae). Journal of Applied Phycology 30:1207-1215. 


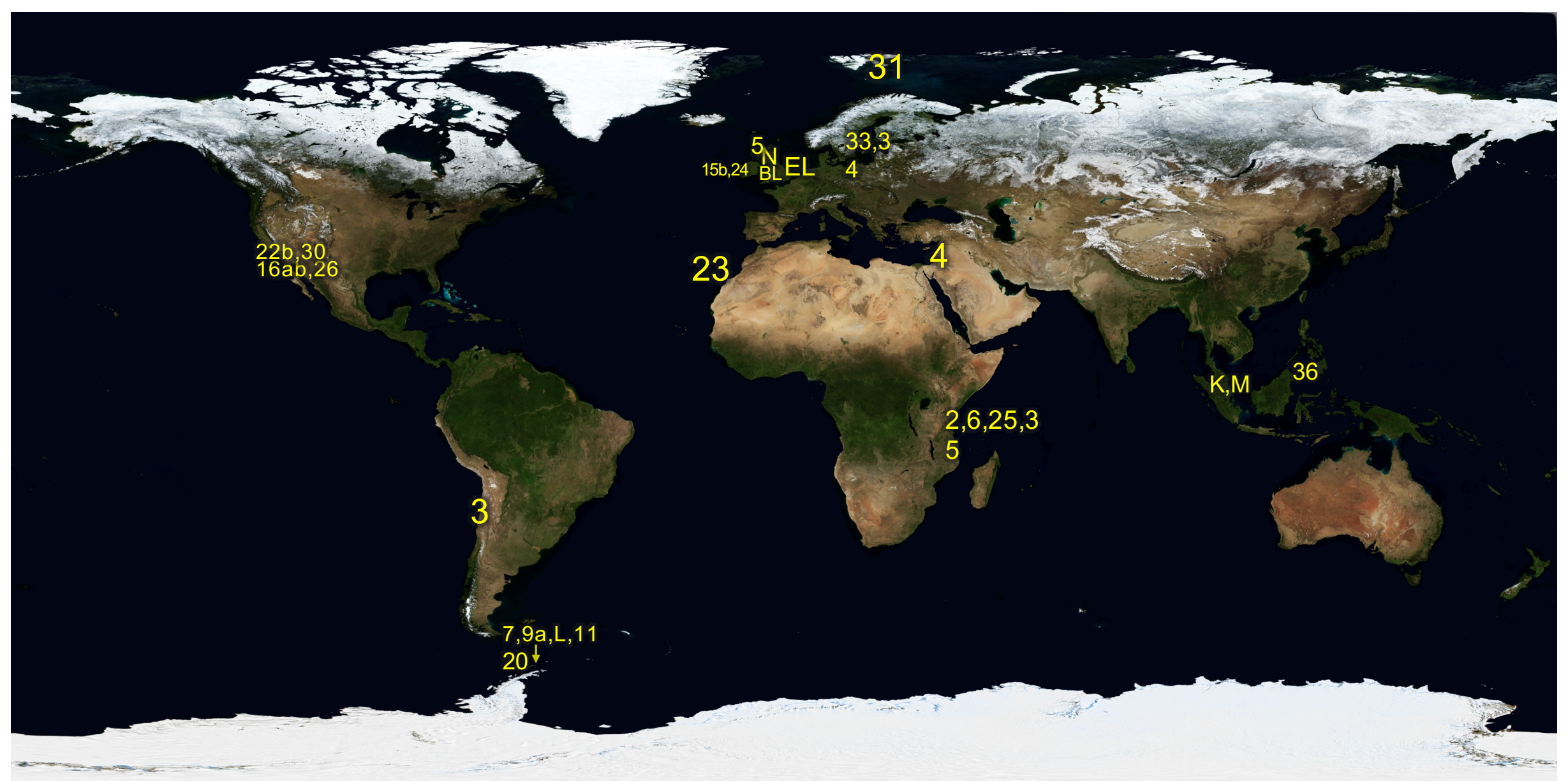

Fig. 1: Geographical overview of the various locations from which seaweeds were collected for studies relating the effect of environmental change on the emission of halocarbon by the seaweeds. Numbers are based according to the Study Number mentioned in Table 2. BL= Study Number 8, 10, 12b, 13-15a, 21, 22a, 41b-43a, 44, 45a, 46; $\mathrm{EL}=43 \mathrm{~b}, 45 \mathrm{~b} ; \mathrm{K}=$ Study Number 17-19, 27-29; L= Study Number 9b, 32, 47, 48; M= Study Numbers 37 - 40; N= Study Number 1, 12a, 41a. Photo credit: NASA Earth Observatory 
Table 1: Compilation of halocarbon emission rates reported in the literature for a range of tropical, temperate and polar seaweeds, arranged in descending rate of emission. In each case the emission rate ( $\mathrm{pmol} \mathrm{g} \mathrm{FW}^{-1} \mathrm{hr}^{-1}$ and/or pmol $\mathrm{g} \mathrm{DW}^{-1} \mathrm{hr}^{-1}$ ) is provided for the dominant halocarbon emitted by the species.

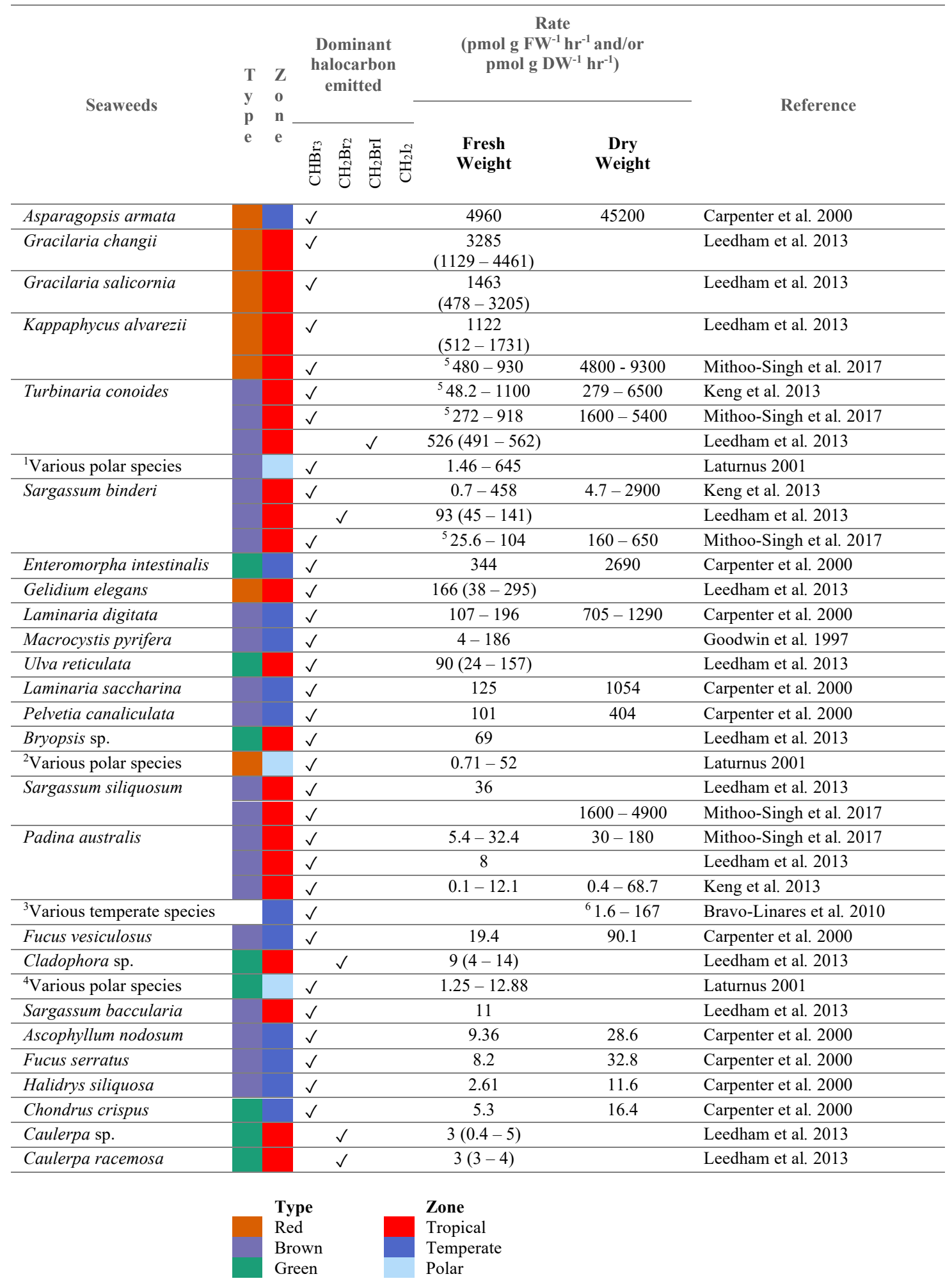


${ }^{1}$ Desmarestia antarctica, Desmarestia anceps, Desmarestia menziesii, Himantothallus grandifolius, Cystosphaera jaquinotii, Fucus distichus, Dictyosiphon foeniculaceus, Laminaria saccharina, Laminaria solidungula, Chordaria flagelliformis, Alaria esculenta; ${ }^{2}$ Kallymenia Antarctica, Plocamium coccineum, Gymnogongrus antarcticus, Gigartina skottsbergii, Iridaea cordata, Palmaria decipiens, Myriogramme mangini, Curdiea racovitzae, Devalarea ramentacea, Plocamium cartilagineum, Pantoneura plocamioides; ${ }^{3}$ Brown seaweeds Ascophyllum nodosum, Fucus vesiculosus, Fucus serratus, Laminaria digitata, green seaweeds Ulva lactuca, Ulva intestinalis, and red seaweeds Palmaria palmata, Griffithsia flosculosa; ${ }^{4}$ Enteromorpha bulbosa, Enteromorpha compressa, Monostroma arcticum, Blidingia minima, Urospora penicilliformis, Acrosiphonia sonderi, Ballia callitricha, Lambia Antarctica; ${ }^{5}$ Converted based on assumption of moisture content of $\sim 90 \%$ on $K$. alvarezii, $\sim 83 \%$ for $T$. conoides, $\sim 84 \%$ for $S$. binderi, and $\sim 82 \%$ for $P$. australis (our unpublished data); ${ }^{6}$ Values represent range for all seaweed species from Bravo-Linares et al. 2013, as individual readings for each species is not reported. 
Table 2: A summary of studies on the emissions of halocarbons by seaweeds, arranged by experimental treatment or the stress factor applied.

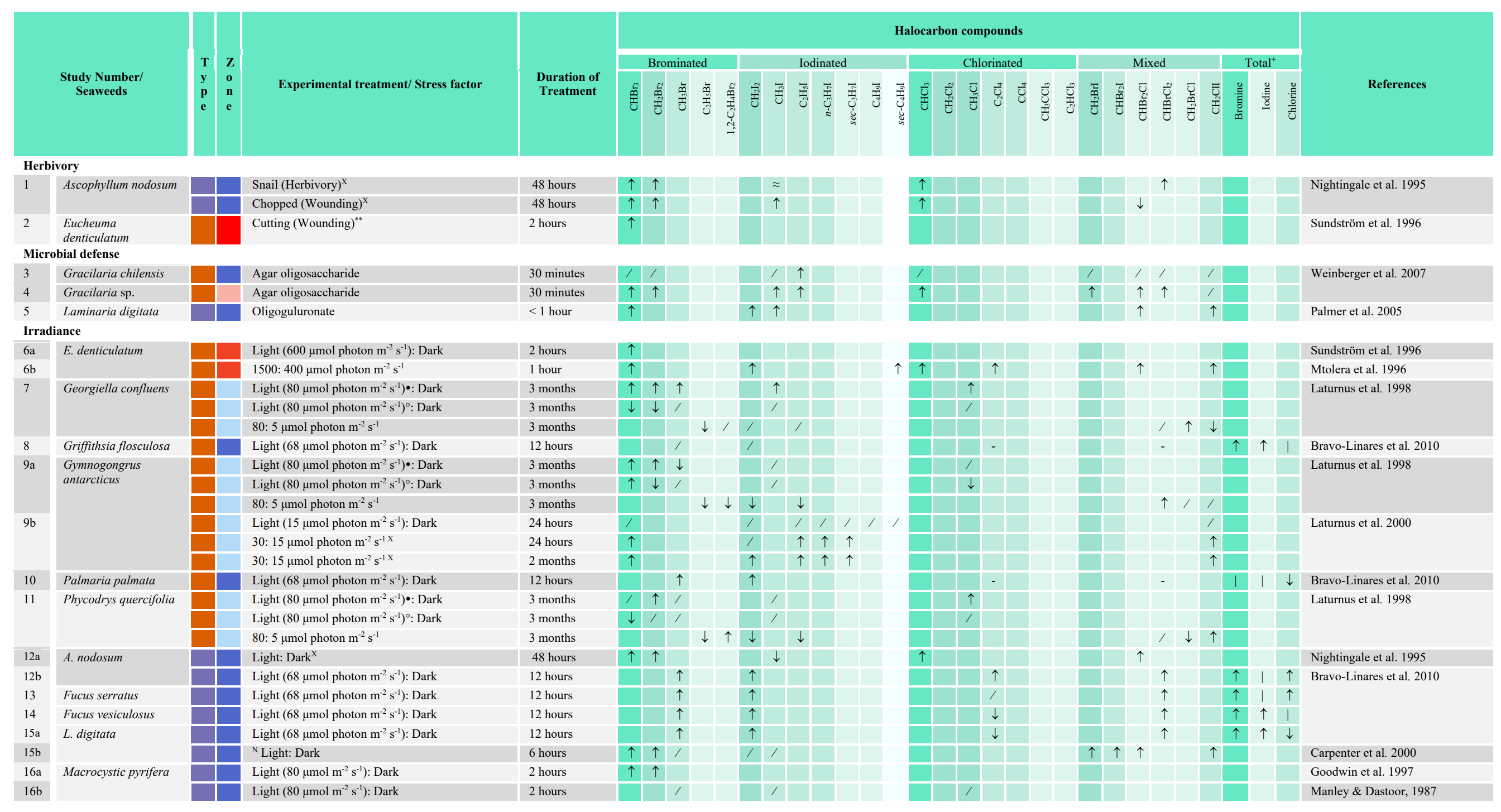




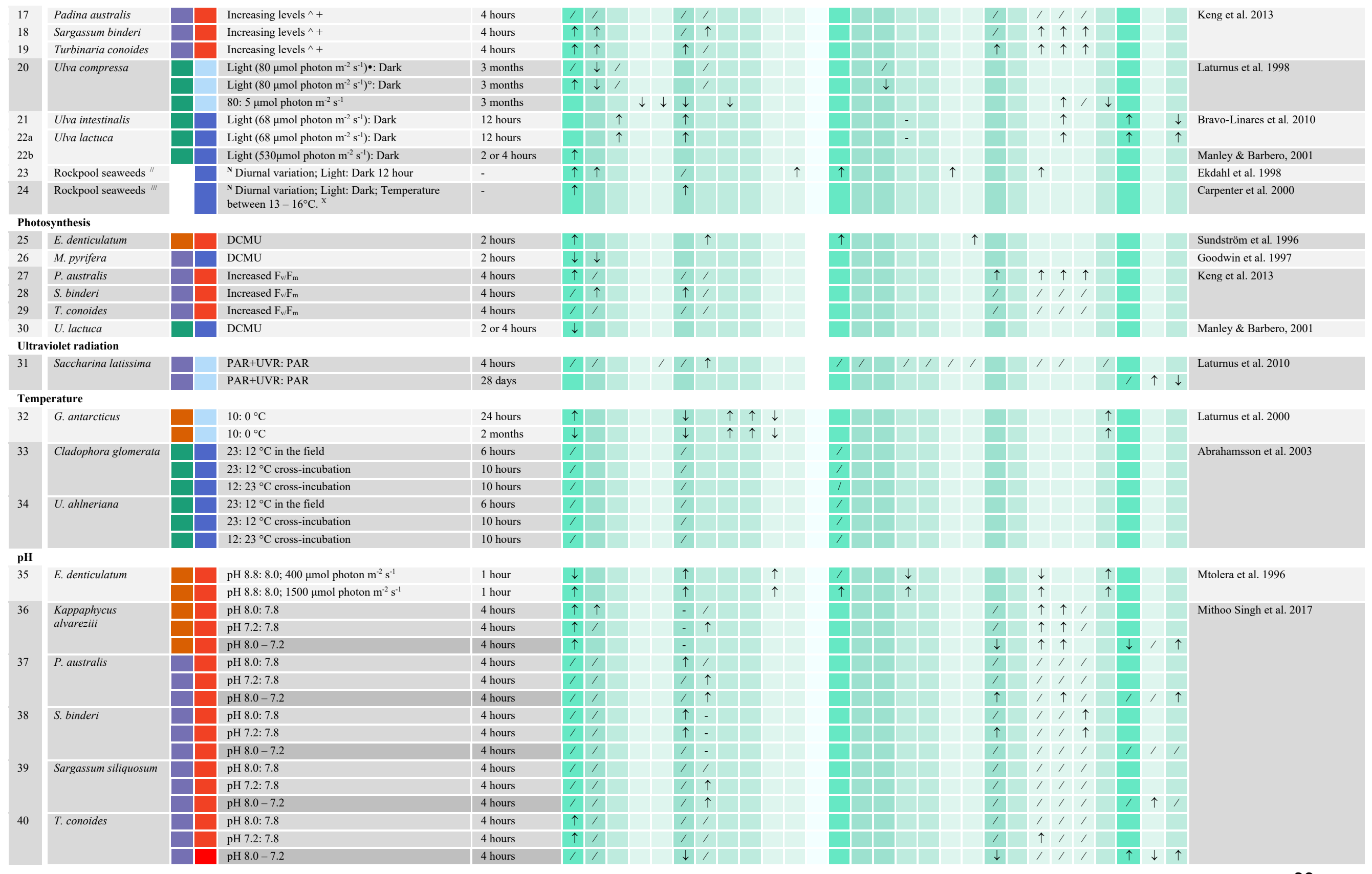




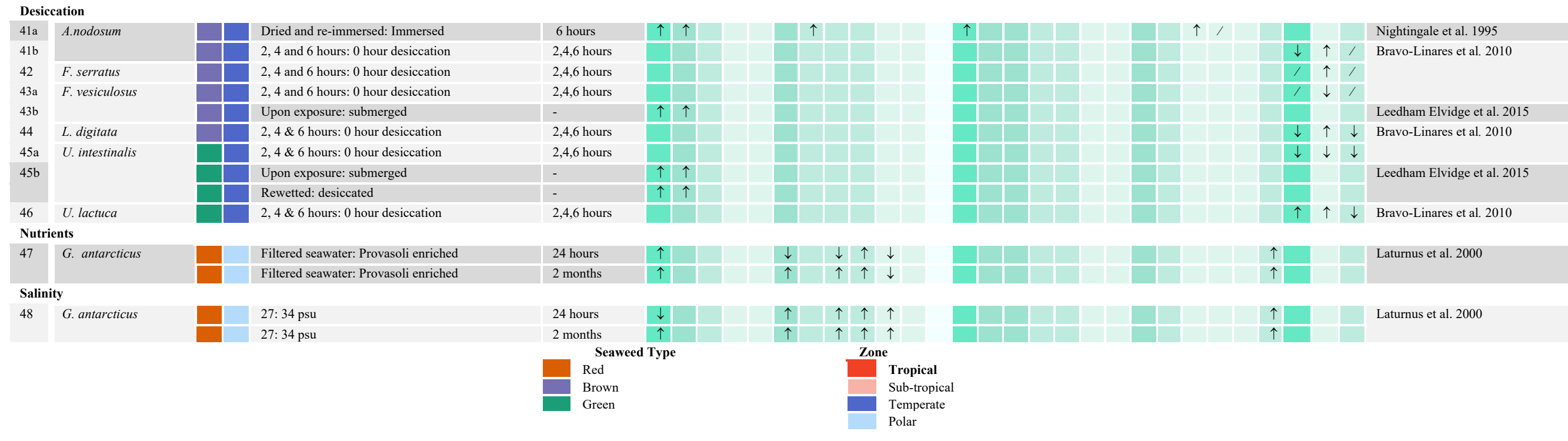

Rockpool seaweeds arranged according to decreasing abundance:

"including Cystoseria abies-marina, Codium adherens, Grateloupia doryphore, Hypnea spinella, Sargassum sp., Spirida hypnoides, Padina pavonia; III including Enteromorpha prolifera, Cladophora rupestris and Ulva sp. covering >50\% of bottom surface, Halopteris scoparia, Fucus serratus, Fucus spiralis, Halidrys siliquosa, Laminaria digitata, Himanthalia elongate, Chondrus crispus, Polysiphonia brodiaei, Corallina elongate, Hildenbrandia rubra, Palmaria palmate, Callithamnion tetragonum, Codium fragile

All studies were conducted under controlled laboratory conditions except those denoted by ${ }^{\mathrm{N}}$ where the studies are conducted in the natural environment; ${ }^{+}$Denotes the total of the brominated, iodinated and chlorinated halocarbons (Bravo-Linares et al. 2010) or the reactive organic halogen which was the molar sum derived from the halocarbon compounds investigated in the respective studies (Laturnus et al. 2010; Mithoo Singh et al. 2017).

$\uparrow$ Increased emission of compounds; $\downarrow$ Decreased emission of compounds; /Insignificant changes in emission; $\approx$ Uncertain effect; ${ }^{\mathbf{x}}$ Statistical significance not stated; | lacking replicates; - Not detected; ${ }^{* *} \mathrm{CHB}_{3}$ production assumed through the formation of tetrabromophenol by brominating activity of the seaweed - the production of $\mathrm{CHBr}_{3}$ was reported as a linear function of brominating activity (production of tetrabromopheol); ${ }^{\wedge} \mathrm{CHBr}{ }_{2} \mathrm{Cl}$, $\mathrm{CHBrCl}_{2}$ and $\mathrm{CH}_{2} \mathrm{BrCl}$ were represented as derivatives of $\mathrm{CHBr}_{3}$; Treatment of $1500 / 40 \mu \mathrm{mol}$ photon $\mathrm{m}^{-2} \mathrm{~s}^{-1}=$ Trend observed based on the irradiance at $1500 \mu \mathrm{mol}$ photon $\mathrm{m}^{-2} \mathrm{~s}^{-1}$ relative to $40 \mu \mathrm{mol}$ photon $\mathrm{m}^{-2} \mathrm{~s}^{-1}$; + Increasing irradiance of $0,47,58,82,126 \mu \mathrm{mol}$ photon $\mathrm{m}^{-2} \mathrm{~s}^{-1} ; \bullet$ Seaweeds acclimatized at 
photoperiod of 6.45 hour; ${ }^{\circ}$ Seaweeds acclimatized at photoperiod of 17.45 hour; Unchecked boxes under the 'Halocarbon Compounds' section indicate compounds not investigated in the respective studies;

DCMU = 3-(3,4-dichlorophenyl)-1,1-dimethylurea; PAR = Photosynthetically Active Radiation; cross-incubation indicates a temperature change in the laboratory from the field 